EJIM

24,5

1832

Received 16 April 2020

Revised 2 June 2020

11 August 2020

Accepted 29 September 2020

\section{Trust, knowledge sharing, and innovative work behavior: empirical evidence from Poland}

\author{
Roman Kmieciak \\ Faculty of Organization and Management, Silesian University of Technology, \\ Gliwice, Poland
}

\begin{abstract}
Purpose - The purpose of this paper is to assess the effects of two types of trust (vertical and horizontal trust) on knowledge sharing (knowledge donating and knowledge collecting) and the impact of knowledge sharing on innovative work behavior (idea generation and idea realization). The study also explores the mediating role of knowledge sharing.
\end{abstract}

Design/methodology/approach - Partial least squares path modeling and data collected from 252 participants at one large Polish capital group were used to test the research hypotheses.

Findings - The results showed that both vertical trust and horizontal trust are positively related to knowledge donating and knowledge collecting. Contrary to knowledge collecting, knowledge donating is significantly related to idea generation, which is highly correlated with idea realization. There is no direct relation between knowledge sharing behavior and idea realization. Knowledge donating mediates the relationship between vertical trust and idea generation.

Research limitations/implications - Self-reports and the cross-sectional nature of the data collection are the main limitations of this study.

Practical implications - The results allow managers to better understand what factors and processes contribute to greater employee innovativeness.

Originality/value - To the best of the author's knowledge, the study is the first to examine the relationships among vertical trust, horizontal trust, knowledge donating, knowledge collecting, idea generation and idea realization in an integrated way. This paper answered the questions (1) which type of trust is more important for knowledge sharing, and (2) which type of knowledge sharing behavior is more important for innovative work behavior. This paper investigated whether differences in the strength of relationships between constructs are significant.

Keywords Trust, Vertical trust, Horizontal trust, Knowledge sharing, Knowledge donating, Knowledge collecting, Innovative work behavior, Idea generation, Idea realization

Paper type Research paper

\section{Introduction}

Trust and its impact on collaboration and different work-related outcomes have attracted much research attention in the last two decades. As previous studies show, a high level of trust among employees greatly benefits an organization. Results show that (interpersonal) trust among employees is positively related to job satisfaction (Guinot et al., 2014; Safari et al., 2020; Straiter, 2005), organizational commitment (Curado and Vieira, 2019), task performance (Kim et al., 2018) and team performance (De Jong et al., 2016), and negatively related to stress (Guinot et al., 2014). Research also suggests that trust is significantly positively associated with knowledge sharing (KS) in the workplace (Abdelwhab Ali et al., 2019; Hsu and Chang, 2014; Nerstad et al., 2018; Ouakouak and Ouedraogo, 2019; Renzl, 2008; Rutten et al., 2016;

(C) Roman Kmieciak. Published by Emerald Publishing Limited. This article is published under the Creative Commons Attribution (CC BY 4.0) licence. Anyone may reproduce, distribute, translate and create derivative works of this article (for both commercial and non-commercial purposes), subject to full attribution to the original publication and authors. The full terms of this licence may be seen at http:// creativecommons.org/licences/by/4.0/legalcode
European Journal of Innovation Management Vol. 24 No. 5,2021 pp. $1832-1859$ Emerald Publishing Limited 1460-1060

DOI 10.1108/EJIM-04-2020-0134 
Staples and Webster, 2008), although contrary findings were also found (Bakker et al., 2006; Chow and Chan, 2008). The mixed results may be due to the fact that researchers usually do not distinguish between different types of trust in terms of their impact on different knowledge-sharing behavior. Therefore, our understanding on how trust affects knowledge sharing is not adequate. In particular, it is important to distinguish between knowledge donating $(\mathrm{KD})$ and knowledge collecting $(\mathrm{KC})$, because these two behaviors are of a different nature and therefore may be affected by different individual, organizational and technological factors (de Vries et al., 2006; Razmerita et al., 2016). Moreover, trust can be viewed from different perspectives (Feitosa et al., 2020; McCauley and Kuhnert, 1992; Paliszkiewicz, 2018), and separately analyzing trust in co-workers (horizontal trust, HT) and trust in superiors (vertical trust, VT) is justified because it may provide different findings (Hughes et al., 2018). However, there have been few empirical studies on relationships between horizontal/vertical trust and knowledge donating/collecting (Le and Lei, 2018). Furthermore, no studies have clarified the question of whether vertical or horizontal trust is more strongly related to knowledge donating/collecting.

Other streams of research focus on trust and KS as factors that may have a positive impact on innovative work behavior (IWB). Under social exchange theory, interpersonal trust between coworkers leads to greater sense of security in the workplace (Erkutlu and Chafra, 2015), organizational commitment and, consequently, engagement in innovative work behavior (Yu et al., 2018). In turn, KS leads to the exchange of experiences and skills between employees, contributes to collective learning and evokes reflection on current knowledge (Chen et al., 2010; Michna, 2018). Thus, KS increases the chances of becoming involved in additional, non-routine activities, such as innovative work behaviors (Anser et al., 2020). As Liua and Phillips (2011) noted, in most cases the employee has too little knowledge and too few opportunities to implement innovations himself/herself. It is only by collaboration with other employees that a synergy effect appears and innovative ideas can be implemented successfully. Generally, previous research confirms the positive relationship between trust and IWB (Afsar et al., 2020; Barczak et al., 2010; Yu et al., 2018) and between KS and IWB (Anser et al., 2020; Kim and Park, 2017; Mura et al., 2013; Radaelli et al., 2014). Surprisingly, no studies exist that show in more detail which forms of trust and knowledge sharing behavior positively affect the separate processes of IWB. Furthermore, to date, research on a relationship between trust and IWB has not considered the mediating role of KS behavior.

The present study addresses this gap and develops a research model to link interpersonal trust among employees in an organization, knowledge sharing within an organization and IWB. This study explores the relationships among these constructs more deeply than previous studies by analyzing two types of trust (vertical and horizontal), two KS behaviors (knowledge donating and collecting), and two IWB processes (idea generation and idea realization). Moreover, the study investigates the mediating effect of two KS behaviors on the relationship between trust and IWB. The study aims to answer the following questions: How does interpersonal trust among employees shape knowledge sharing behaviors in the workplace? Which trust - vertical or horizontal - is more strongly related to knowledge donating/collecting? How does knowledge sharing shape innovative work behavior? Which knowledge sharing behavior is more strongly related to idea generation/realization? Which knowledge sharing behavior mediates the relationship between trust and IWB?

The main contribution of the paper lies in providing a fuller picture of the relationships among trust, KS and IWB. Although both trust and knowledge sharing have been found to be related to innovative work behavior individually, their integrated impact on IWB has not yet been investigated. In addition to using relatively less explored dimensions of trust, KS and IWB, the study investigates the mediating effects of two KS behaviors on the relationships between trust and IWB. These extensions create a more detailed picture of the conditions and
Trust, knowledge sharing, and innovative work behavior

1833 
EJIM

24,5

\section{4}

processes that reinforce specific components of IWB. Therefore, the results can offer useful suggestions to managers interested in promoting KS and increasing innovation.

The remainder of the paper is organized as follows. First, the literature review defines the constructs that are the subject of this study and establishes the relationships between them. The 13 hypotheses are then stated. Next, the methodology of the empirical research is described. Finally, the results are presented and discussed.

\section{Literature review and hypotheses development}

This study uses theories of social exchange, cognitive psychology, and self-learning mechanism to develop a conceptual model of the relationships between trust, knowledge sharing and innovative work behavior.

\subsection{Horizontal and vertical trust}

The concept of trust has many definitions (see Table 1) and can be viewed from different perspectives (Feitosa et al., 2020; Tomlinson et al., 2020), including individual expectations or as part of a social or economic exchange (Paliszkiewicz, 2018). Trust is usually defined as a

\begin{tabular}{|c|c|}
\hline Author & Definition of trust \\
\hline $\begin{array}{l}\text { Rotter (1967), } \\
\text { p. } 651\end{array}$ & $\begin{array}{l}\text { "Interpersonal trust is an expectancy held by an individual or a group that the word, } \\
\text { promise, verbal or written statement of another individual or group can be relied upon" }\end{array}$ \\
\hline Zand (1972), p. 230 & $\begin{array}{l}\text { "Trusting behavior is defined here as consisting of actions that (a) increase one's } \\
\text { vulnerability, (b) to another whose behavior in not under one's control, (c) in a situation in } \\
\text { which the penalty (disutility) one suffers if the other abuses that vulnerability is greater } \\
\text { than the benefit (utility) one gains if the other does not abuse that vulnerability" }\end{array}$ \\
\hline $\begin{array}{l}\text { Boon and Holmes } \\
\text { (1991), p. } 194\end{array}$ & $\begin{array}{l}\text { "Trust is a state involving confident positive expectations about another's motives with } \\
\text { respect to oneself in situations entailing risk" }\end{array}$ \\
\hline $\begin{array}{l}\text { Mayer et al. (1995), } \\
\text { p. } 712\end{array}$ & $\begin{array}{l}\text { "Trust is the willingness of a party to be vulnerable to the actions of another party based } \\
\text { on the expectation that the other will perform a particular action important to the trustor, } \\
\text { irrespective of the ability to monitor or control that other party" }\end{array}$ \\
\hline $\begin{array}{l}\text { Mishra (1996), } \\
\text { p. } 265\end{array}$ & $\begin{array}{l}\text { "Trust is one party's willingness to be vulnerable to another party based on the belief } \\
\text { that the latter party is (1) competent, (2) open, (3) concerned, and (4) reliable" }\end{array}$ \\
\hline $\begin{array}{l}\text { Bhattacharya et al. } \\
\text { (1998), p. } 462\end{array}$ & $\begin{array}{l}\text { "Trust is an expectancy of positive (or nonnegative) outcomes that one can receive based } \\
\text { on the expected action of another party in an interaction characterized by uncertainty" }\end{array}$ \\
\hline $\begin{array}{l}\text { Das and Tang } \\
\text { (1998), p. } 494\end{array}$ & $\begin{array}{l}\text { "Trust is the degree to which the trustor holds a positive attitude toward the trustee's } \\
\text { goodwill and reliability in a risky exchange situation" }\end{array}$ \\
\hline $\begin{array}{l}\text { Lewicki } \text { et al. } \\
\text { (1998), p. } 439\end{array}$ & "confident positive expectations regarding another's conduct" \\
\hline $\begin{array}{l}\text { Rousseau et al. } \\
\text { (1998), p. } 395\end{array}$ & $\begin{array}{l}\text { "Trust is a psychological state comprising the intention to accept vulnerability based } \\
\text { upon positive expectations of the intentions or behavior of another" }\end{array}$ \\
\hline $\begin{array}{l}\text { Tschannen-Moran } \\
\text { and Hoy (2000), } \\
\text { p. } 556\end{array}$ & $\begin{array}{l}\text { "Trust is one party's willingness to be vulnerable to another party based on the } \\
\text { confidence that latter party is (a) benevolent, (b) reliable, (c) competent, (d) honest and } \\
\text { (e) open" }\end{array}$ \\
\hline $\begin{array}{l}\text { Tzafrir and Eitam- } \\
\text { Meilik (2005), } \\
\text { p. } 196\end{array}$ & $\begin{array}{l}\text { "Trust is the willingness to increase the resources invested in another party, based on } \\
\text { positive expectations resulting from past positive mutual interactions" }\end{array}$ \\
\hline Six (2007), p. 290 & $\begin{array}{l}\text { "Interpersonal trust is a psychological state comprising the intention to accept } \\
\text { vulnerability to the actions of another party, based upon the expectation that the other } \\
\text { will perform a particular action that is important to you" }\end{array}$ \\
\hline Ahteela and & "Interpersonal trust is defined as the positive expectations of individuals about the \\
\hline $\begin{array}{l}\text { Vanhala (2018), } \\
\text { p. } 4\end{array}$ & $\begin{array}{l}\text { competence, benevolence, and reliability of the organizational members on lateral and } \\
\text { vertical levels under risk-prone conditions" }\end{array}$ \\
\hline
\end{tabular}

Table 1.

Definitions of interpersonal trust
Vanhala (2018), p. 4 
state, belief, or positive expectation (Six, 2007). It is related to a belief and confidence that another party will behave in an ethical, predictable and fair manner (Sarwar and Mumtaz, 2017). McCauley and Kuhnert (1992) noticed that trust is a multidimensional construct, and Tschannen-Moran and Hoy (2000) claimed that definitions of trust often include such aspects as, first of all, vulnerability, but also benevolence, reliability, competence, honesty and openness.

Because this paper focuses on interpersonal trust between organizational members, it adopts the definition of trust proposed by Ahteela and Vanhala (2018; see Table 1). Their definition of interpersonal trust is based on four elements: an individual disposition ("the positive expectations of individuals"), desirable features in others ("competence, benevolence, and reliability of the organizational members"), distinguishing between vertical and horizontal trust ("on lateral and vertical levels") and situational parameters ("under riskprone conditions").

In the environment of an organization, organization members may trust their supervisors but distrust their coworkers, or the converse. Therefore, it is important to distinguish between vertical and horizontal (also called lateral) trust. Vertical trust refers to trust relations between an employee and his or her immediate supervisor or top management, whereas horizontal trust refers to trust relations between an employee and his or her peers or equals who are in a similar work situation (McCauley and Kuhnert, 1992). Those two types of interpersonal trust may have a different impact on employees' behavior and performance. For example, Hughes et al. (2018) found that the relationship between IWB in a team and team performance is most positive when horizontal trust is high and vertical trust is low. To explain this result, the authors suggested that when vertical trust is high, employees might not critically evaluate their innovative behaviors because they know that their supervisors support them regardless of the results of their initiatives.

\subsection{Knowledge sharing behaviors}

The concept of knowledge sharing is widely discussed in the management literature. It is one of the key processes in knowledge management that precedes the exploitation of knowledge. Knowledge sharing is viewed as a behavior (process or operation) through which individuals mutually exchange their knowledge (information, skills, and expertise; Mirzaee and Ghaffari, 2018; van den Hooff and de Ridder, 2004). In the context of organizations, knowledge sharing among employees involves valuable implicit or explicit knowledge, leads to new knowledge creation, develops organizational knowledge and brings benefits to the organization. In particular, knowledge sharing enhances innovativeness at an individual (Kim and Park, 2017) and organizational (Lin, 2007; Michna, 2018; Pittino et al., 2018) level.

Two active processes (or behaviors) are distinguished in knowledge sharing: knowledge collecting and knowledge donating. Knowledge collecting (gaining or receiving) refers to consulting others for their intellectual capital in order to learn what they know, whereas knowledge donating (disseminating or bringing) is communicating one's personal intellectual capital to others (van den Hooff and de Ridder, 2004; de Vries et al., 2006).

It is important to distinguish between knowledge sharing behaviors and attitudes. Behaviors can be seen as actual actions that result from attitudes. As de Vries et al. (2006) noted, knowledge sharing behaviors greatly depend on one's attitude - his or her willingness to share knowledge. Willingness reflects an individual's preparation and readiness to grant others access to his or her intellectual capital. People who are willing to share knowledge are focused on the interest of a group and on expected reciprocity; that is, that other members of the group will also share knowledge. de Vries et al. (2006) distinguished between willingness and eagerness to share knowledge, defining the latter as an individual's strong internal drive to donate his or her knowledge without expecting reciprocity. The benefits for eager people are peer recognition and increased reputation (de Vries et al., 2006). 
EJIM 24,5

1836
As knowledge sharing has the potential to improve firm performance (Peralta and Saldanha, 2014), an important issue for organizations is which factors influence both knowledge donating and knowledge collecting. Those factors may be of an individual, organizational or technological nature (see Razmerita et al., 2016). Generally, information and communication technology is said to directly or indirectly facilitate knowledge sharing (Choi et al., 2010; Mirzaee and Ghaffari, 2018; Yuan et al., 2013). Knowledge sharing is supported by an appropriate organizational culture and climate (Al-Alawi et al., 2007; Mueller, 2012; Suppiah and Singh Sandhu, 2011), including a constructive communication climate (van den Hooff and de Ridder, 2004), management support (Paroutis and Al Saleh, 2009), reward systems (Amayah, 2013) and employees' affective commitment to the organization (Casimir et al.,2012). In addition, one of the factors most often indicated as affecting knowledge sharing is trust (Al-Alawi et al., 2007; Casimir et al., 2012; Chen and Hung, 2010; Paroutis and Al Saleh, 2009; Rutten et al., 2016).

\subsection{Trust and knowledge sharing}

The influence of trust on the employees' propensity to share knowledge is important for the organization's innovation. The more someone trusts another person, the greater his or her willingness to share knowledge with that person, for several reasons. First, when trusting a person, we believe that the knowledge transmitted to that person will be used appropriately (Staples and Webster, 2008) and not be used against us, even if this knowledge is incomplete, imperfect or containing errors. We believe that the knowledge provided will not be used to criticize or undermine our competences. For example, a subordinate who trusts his or her supervisor will be more willing to reveal his or her limitations in skills, abilities, and knowledge if he or she trusts the superior not to use this knowledge against him or her (McEvily et al., 2003).

What's more, if we trust a person, we expect reciprocity and believe that the other party will share knowledge with us. This expectation of reciprocity is confirmed in the literature on social exchange theory (see Cropanzano and Mitchell, 2005) and social capital theory (see Hsu and Chang, 2014). Finally, trust affects knowledge collecting. The recipient of knowledge is less apt to verify the accuracy and truthfulness of knowledge that comes from a trusted source. Under such conditions, the recipient does not have to spend time and effort verifying the acquired knowledge but can use it immediately, which speeds up organizational learning, alertness and responsiveness (McEvily et al., 2003).

Empirical research confirms the existence of a relationship between trust and knowledge sharing. Hsu and Chang (2014), Renzl (2008), and Staples and Webster (2008), among others, found a positive relationship between interpersonal trust and knowledge sharing. However, contrary results have also been found. For example, Chow and Chan (2008) did not find a positive relationship between social trust and knowledge sharing among Hong Kong managers. Bakker et al. (2006) claimed that "trust is a poor explanatory of knowledge sharing" (p. 594).

Some researchers distinguish between trust in colleagues and trust in superiors. For example, Dirks and Ferrin (2002) found that trust in a leader is positively related with job satisfaction, organizational commitment, and confidence in information given by that leader. Whisnant and Khasawneh (2014) concluded that trust facilitates the process of supervisors accruing tacit knowledge from their subordinates. When it comes to trust among coworkers, Politis (2003) proved that faith and confidence in one's peers is positively related to communication and understanding problems. Al-Alawi et al. (2007) confirmed that trust and knowledge sharing among coworkers are related.

Taking into account the above considerations, both trust between employees and trust in a superior can have a positive impact on the behavior associated with sharing knowledge with colleagues. Thus, the following hypotheses are proposed: 
H1. Horizontal trust is positively related to (a) knowledge donating and (b) knowledge collecting.

H2. Vertical trust is positively related to (a) knowledge donating and (b) knowledge collecting.
Trust, knowledge sharing, and innovative work behavior

An interesting question is whether the strength of the relationship between trust and knowledge sharing behaviors depends on whether the trust is in a supervisor or colleagues.

On the one hand, when employees trust their direct leaders (that is, their supervisors), they feel confident and comfortable donating their knowledge. Knowledge donating requires courage and faith that the knowledge will not be used against the knowledge sender. As Mayer et al. (1995) suggested, if supervisors have high levels of integrity, ability and benevolence, employees are more willing to trust the supervisors, take risks in their relationships with the supervisors, and reveal information, including sensitive information about mistakes or shortcomings. Hence, employees will be more willing to share knowledge if they feel support from their supervisors.

On the other hand, it seems logical to claim that employees are more willing to donate their knowledge to coworkers and collect knowledge from their coworkers when they trust them. The reasoning is similar to that in the case of the relationship between the subordinate and the supervisor. If an employee communicates knowledge to his or her colleagues, he or she wants to believe that this knowledge will be used properly and will not be used against him or her. The more trust, the stronger the faith. If an employee collects knowledge from a trusted colleague, he or she believes that he or she is not being deliberately misled and that the information obtained is true.

Previous research indicates that trust in colleagues is more important for knowledge sharing than trust in superiors. Wu et al. (2009) found that in high-tech industries in Taiwan both trust of colleagues and trust of a supervisor are positively correlated with knowledge sharing behavior, but that trust of colleagues has a stronger relationship with knowledge sharing than trust of a supervisor. Similarly, based on research conducted in a large Australian automotive company, Lee et al. (2010) concluded that "trust in the team is a better predictor of team knowledge sharing than trust in the leader" (p. 485).

The cultural context may impact the relationship between trust and knowledge sharing among leaders and employees. Poland is a hierarchical society (Insights, 2018). Centralization is popular in organizations, and subordinates expect to be told what to do. Moreover, in Polish society there is a strong preference to avoid uncertainty; people are intolerant of unconventional behaviors and ideas, and security is very important in their lives (Insights, 2018). Under these conditions, an employee's relationship with a supervisor might have stronger impacts on the employee's attitudes toward knowledge sharing than relationships with coworkers. Although previous research conducted in Poland confirms that trust positively affects knowledge sharing (Kucharska and Kowalczyk, 2016b; Sankowska, 2013; Spałek et al., 2018), no research clearly indicates whether vertical or horizontal trust has a greater impact on knowledge donating and collecting in Polish companies.

The above discussion results in the following hypotheses:

H3. The strength of the relationship between vertical trust and knowledge donating is significantly different from the strength of the relationship between horizontal trust and knowledge donating.

H4. The strength of the relationship between vertical trust and knowledge collecting is significantly different from the strength of the relationship between horizontal trust and knowledge collecting. 
EJIM

24,5

1838

\subsection{Innovative work behavior}

Organizational innovativeness results from individual innovativeness (Hughes et al., 2018; Spanuth and Wald, 2017). Therefore, there is great interest in innovative work behavior as the source of organizational success (Dorenbosch et al., 2005; Janssen, 2000). Following Janssen (2000), and Yuan and Woodman (2010), innovative work behaviors is defined here as the intentional creation and application of new ideas or innovations (new products or processes) in the workplace to improve individual, group, or organization performance. The definition indicates that innovative work behavior is closely related with other concepts in the literature, such as employee innovativeness, innovative job performance and on-the-job innovation (Spanuth and Wald, 2017). Innovative work behavior is a complex concept that may include such behavioral activities as idea exploration, generation, promotion and implementation (Dorenbosch et al., 2005; Scott and Bruce, 1994; Spanuth and Wald, 2017). Consequently, innovative work behavior is regarded as one (Jansen, 2000; Scott and Bruce, 1994), two (Dorenbosch et al., 2005; Krause, 2004), or even four (De Jong and Den Hartog, 2010; Spanuth and Wald, 2017) dimensional construct.

This paper focuses on two components of IWB: idea generation and idea realization. Idea generation is defined as a creative behavior aimed at searching for and generating new, original approaches and solutions to problems, including new working methods and techniques. Idea realization refers to implementing new ideas in the form of new products or processes in an organization. Axtell et al. (2000) noted that the distinction between idea generation and idea realization has reasoning in a different etiology. Idea generation depends on individual characteristics (an individual's creativity, self-confidence, job knowledge and job demands) than group and organizational characteristics. In contrast, idea realization, as a social process, affects other employees. Its success depends on the other's approval, engagement and support. Simple innovations are usually introduced by individual employees, but more complex ones need cooperation, and various knowledge inputs and competences (Jansen, 2000).

Innovation is perceived as a multi-stage process, with the general agreement that idea generation is followed by idea realization (De Jong and Den Hartog, 2010; Krause, 2004; Spanuth and Wald, 2017). Therefore,

H5. Idea generation is positively related to idea realization.

\subsection{Knowledge sharing and innovative work behavior}

The literature review confirms that knowledge sharing is an important process influencing the improvement of innovativeness both at the organizational level (cf. Michna, 2018; Pittino et al., 2018; Zhao et al., 2020) and at the individual level (cf. Anser et al., 2020; Kim and Park, 2017; Mura et al., 2013; Radaelli et al., 2014; Rao Jada et al., 2019). This importance is due to the fact that knowledge plays an important role in creating innovation. Expert knowledge, including knowledge about past solutions and events, can be the basis and inspiration for new solutions. By sharing knowledge with colleagues, the knowledge base of other employees is increased and the chance for the emergence of innovative ideas increases. As noted by Radaelli et al. (2014), "idea generation is a process of knowledge creation that requires recombining internal and external knowledge into new forms" (p. 401). The implementation of ideas cannot usually be accomplished by a single person, but requires cooperation and the knowledge, skills and perspectives of various employees, resulting in a synergy effect (Liua and Phillips, 2011). The ability to accumulate knowledge is important for creating new solutions. For example, the knowledge about clients and their needs gathered by the marketing department is passed to the research and development department, where, in addition to technical knowledge, it is the basis for the development of new products. 
From the point of view of cognitive psychology, the effective absorption of new knowledge requires its cognitive restructuring or elaboration by the learner (Slavin, 1996). Sharing knowledge triggers these processes, because the recipient of the knowledge has to connect and integrate the new knowledge with his or her current knowledge. As a result, knowledge sharing can cause reflection on current knowledge, its verification, and its reinterpretation. As Radaelli et al. (2014) claimed, the knowledge recombination and re-elaboration embedded in knowledge sharing stimulate idea generation and application. Research conducted in Poland among team members confirmed that tacit knowledge sharing has a positive influence on team creativity (Kucharska and Kowalczyk, 2016a).

These considerations lead to the following hypotheses:

H6. Knowledge donating is positively related to (a) idea generation and (b) idea realization.

H7. Knowledge collecting is positively related to (a) idea generation and (b) idea realization.

Previous research suggests that employees' knowledge sharing has a positive impact on the innovative work behavior of both the knowledge receiver (Majchrzak et al., 2004) and knowledge sender (Radaelli et al., 2014). However, an under-researched issue is which knowledge sharing behavior, knowledge collecting or knowledge donating, is more strongly related to IWB.

For a knowledge sender, the positive impact of knowledge donating on IWB might be explained by the self-learning mechanism (Lai et al., 2016). The sender plays the role of a teacher who, before passing knowledge to others, should organize his or her knowledge and codify it so that it is understandable to others. This preparation may trigger reflection on the possessed knowledge, and may lead to the rejection of obsolete knowledge and the clarification of doubts as to the possessed knowledge and cause-and-effect relationships. These processes support the creation of new knowledge, which is the base for innovative solutions. Moreover, the sender usually receives feedback on the knowledge donated. In this way, the sender's knowledge is verified in terms of truthfulness, accuracy and comprehensiveness. The transferred knowledge may not apply under certain conditions. In this case, the feedback provided by the recipients of the knowledge allows the sender to update the original knowledge and contribute to innovative behavior. However, a sender who engages in too much knowledge donating might be less innovative, because the sender has no time to develop innovative ideas.

Knowledge sharing can also benefit the innovative behavior of knowledge receivers. The recipient collects knowledge gained by other people, including their experience and proven and useful solutions and practices. Through the learning process, the recipient of the knowledge combines the knowledge gained from others with his or her own knowledge, which leads to the reinterpretation of the knowledge, updates and even the questioning and rejection of obsolete knowledge. Consequently, the acquired knowledge stimulates the creativity and innovative behavior of the recipient of the knowledge (Lai et al., 2016).

Research conducted among managers and staff of 148 retail units in China showed that the highest level of employees' innovative behavior was achieved when there was a balance between knowledge outflow from the business unit and knowledge inflow into the business unit (Lai et al., 2016). This finding and the above discussion suggest that both knowledge donating and knowledge collecting have an equal impact on an individual's innovative behavior. Therefore the following hypotheses are stated:

H8. The strength of the relationship between knowledge donating and idea generation is not significantly different from the strength of the relationship between knowledge collecting and idea generation. 
EJIM

24,5
H9. The strength of the relationship between knowledge donating and idea realization is not significantly different from the strength of the relationship between knowledge collecting and idea realization.

\subsection{Trust and innovative work behavior}

Trust is a factor that can significantly influence the willingness of employees to undertake non-standard and innovative actions in the workplace. According to social exchange theory (see Cropanzano and Mitchell, 2005), the more employees trust the organization, the more work and energy they are willing to devote to working in the organization. If an employee trusts his or her colleagues and supervisors, then he or she will show greater organizational commitment, pro-activity and risk-taking (Dirks and Ferrin, 2002; Colquitt et al., 2007). Specifically, the greater the employees' trust in the supervisor, the greater the sense of security and comfort when it comes to the supervisor's reaction to the subordinate's behavior (Erkutlu and Chafra, 2015). As a consequence, the chance of an employee engaging in innovative behavior increases (Mayer et al., 1995; Hughes et al., 2018), which is usually associated with the risk of failure. On the other hand, when there is a lack of trust, employees will focus more on self-protection than on entrepreneurial behavior (Hughes et al., 2018). Both horizontal and vertical trust can play an important role for innovative behaviors. As Hughes et al. (2018) noted, "trust among the team members provides the lubricant for individuals to jointly devise new plans and actions" (p. 755). Where employees have a bond of trust, collaborative discussions and debates develop that stimulate new useful ideas (Yu et al., 2018). If an employee trusts his/her supervisor, then he/she is willing to take more risky actions without fear that he/she will be punished by the supervisor if his/ her ideas and actions do not bring the intended results (Hughes et al., 2018). The empirical research to date confirms the relationship between trust and innovative behavior (Afsar et al., 2020; Yu et al., 2018) and creativity (Barczak et al., 2010). Thus, the following hypotheses are proposed:

H10. Horizontal trust is positively related to (a) idea generation and (b) idea realization.

H11. Vertical trust is positively related to (a) idea generation and (b) idea realization.

The previous considerations suggest that trust has a positive impact on knowledge donating and collecting, which in turn facilitates idea generation and realization. Therefore, knowledge sharing can play the role of a bridge linking interpersonal trust to employee innovative behavior. This is in line with Hughes et al.'s (2018) claim that "the team conditions generated by higher levels of horizontal trust produce higher levels of information exchange and cooperative behaviour (...) and set a team climate commensurate with innovation activity" (p. 755). Similarly, Afsar et al. (2020) noted that "trust motivates employees to collaborate and support each other's ideas through reciprocity and knowledge sharing”. Moreover, under social exchange theory, employees usually reciprocate for high vertical trust through increased knowledge sharing and innovation (Hughes et al., 2018). Khorakian et al. (2019) found that knowledge sharing behaviors (sharing best practices and mistakes) mediate the effect of ethical behavior in an organization (including support, benevolence, and respect) on innovative work behaviors in public organizations in Iran. These considerations lead to the following hypotheses:

H12. Knowledge donating mediates the positive relationship between trust and innovative work behavior.

H13. Knowledge collecting mediates the positive relationship between trust and innovative work behavior. 


\subsection{Conceptual model}

Figure 1 presents the theoretical model that guides this study. The relationships between components of the model and the associated hypotheses have been elaborated in the previous subsections. Additionally, the literature suggests that employee education has an impact on these relationships. For example, Le and Lei (2018) indicated that the higher the education, the greater the commitment to knowledge sharing, particularly knowledge collecting. They concluded that "employees who have a higher level of education will have a greater ability and willingness to meet the demands of colleagues in knowledge and information" (Le and Lei, 2018, p. 533). Other studies indicate a significant relationship between education and trust (Charron and Rothstein, 2016; Hooghe et al., 2012). This is explained by the fact that better educated people have better cognitive skills and higher social prestige (Hooghe et al., 2012) and are more tolerant and less suspicious of others (Charron and Rothstein, 2016). However, it should be noted that an insignificant relationship between education level and trust was also reported (Vaughn, 2011). Similarly, mixed results were obtained in research on the relationship between education and innovative work behavior (Bantel and Jackson, 1989; Hanif and Bukhari, 2015; Leong and Rasli, 2014).

\section{Research method}

\subsection{Data collection}

An anonymous survey was conducted among employees of a large Polish organization. Selection of the organization for research was guided by the following premises. First of all, the organization should be large, since large organizations usually have richer experience in knowledge management than small and medium enterprises (Hutchinson and Quintas, 2008; Durst and Runar, 2012; Zieba et al., 2016). In the European Union, large enterprises are those that employ at least 250 employees. In addition, since white-collar employees were the subject of the study, the organization should employ a large number of white-collar employees in order to provide a large sample size. The research was conducted in one of the largest capital groups in Poland, which is one of the 10 largest employers in Poland. This capital group is a global organization that places special emphasis on knowledge, cooperation, and innovative activity. This emphasis is expressed in official documents such as codes of ethics and business strategies. In accordance with the adopted code of ethics, it is fundamental for this organization to share knowledge and experience by employees and to build mutual trust. In addition, according to strategic documents, the goal of the capital group is to increase

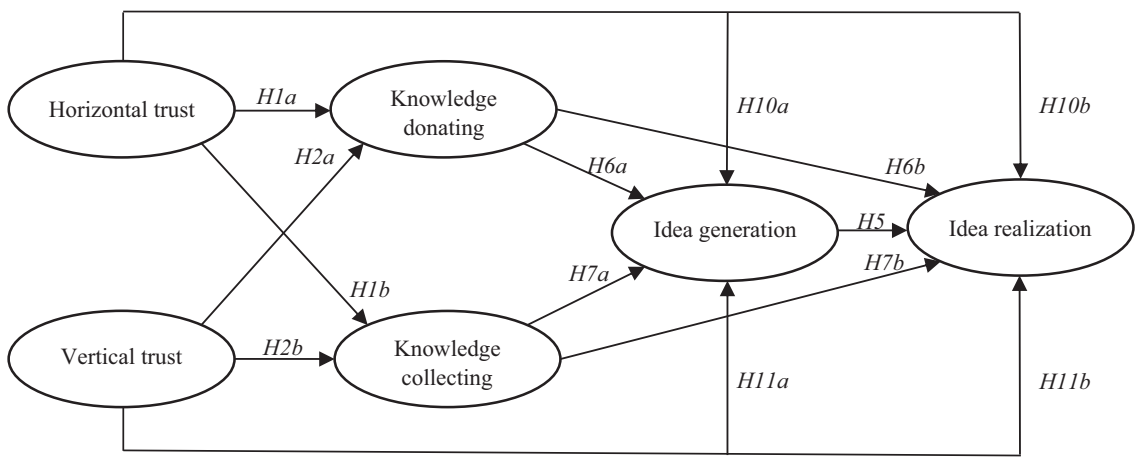

Note(s): The hypotheses $\mathrm{H} 3, \mathrm{H} 4, \mathrm{H} 8, \mathrm{H} 9, \mathrm{H} 12$ and $\mathrm{H} 13$ are not presented due to the clarity of the figure
Trust, knowledge sharing, and innovative work behavior

1841

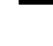


EJIM

24,5

1842

expenditure on innovation fivefold in 2019-2023, to the level of $1 \%$ of revenues in 2023 . Given the above, white-collar employees in this capital group are suitable subjects for this study.

The required sample size was calculated using $\mathrm{G}^{*}$ Power 3.1.9.7 software (Faul et al., 2009). The following parameters were used: the effect size $f^{2}=0.15$, the required significance level $=0.05$, the desired statistical power $=0.95$, and the number of predictors $=5$. On this basis, the minimum sample in this study was 138 respondents.

Respondents were employed in companies belonging to the capital group. The business profiles of these companies included manufacturing machinery and equipment for the mining sector. A link to the questionnaire was sent by e-mail in May 2018 to all 699 white-collar employees from these companies. Data collection lasted one month. During this month, the questionnaire was filled by 252 respondents, which gave a response rate of 36 percent. Table 2 presents the characteristics of the sample.

Since each respondent answered all questions (regarding both independent and dependent variables) at the same time (in one study), there was a risk that the results of the survey might have the common method bias. In order to examine this effect, a Harman single factor test (Podsakoff et al., 2003) was used. The test results indicated that a single factor explained $47 \%$ of the variance, thus below the threshold of 50 percent. Thus, common method bias was not an issue in this study.

\subsection{Measures}

Constructs in this study were measured with previously established and validated multipleitem scales. All items were translated from English into Polish following the back-translation procedure (Brislin, 1986). Responses were scored on a seven-point Likert scale ranging from $1=$ strongly disagree to $7=$ strongly agree.

To measure horizontal and vertical trust, scales developed by Hughes et al. (2018) were used. Knowledge donating and knowledge collecting were measured with scales taken from de Vries et al. (2006). The scales for idea generation and idea realization were derived from Spanuth and Wald (2017). The Appendix provides a full list of scale items.

\begin{tabular}{lcc}
\hline View sample & Frequency & $(\%)$ \\
\hline Gender & & \\
Male & 117 & 46.0 \\
Female & 135 & 54.0 \\
Total & 252 & 100 \\
Age (years) & & \\
Below 30 & 46 & 18.3 \\
30-39 & 93 & 36.9 \\
40-49 & 59 & 23.4 \\
Above 49 & 54 & 21.4 \\
Total & 252 & \\
Education degree & & \\
Bachelor's degree and above & 202 & 80.2 \\
Other & 50 & 19.8 \\
Total & 252 & \\
Job position & & 27.4 \\
Manager & 69 & 72.6 \\
Non-manager & 183 & 100 \\
Total & 252 &
\end{tabular}

Table 2.

Demographic characteristics of the sample

Non-manager 
The literature review indicates that education might impact knowledge sharing (Le and Lei, 2018). Therefore, education was a control variable in this study. Education level was coded into two categories: (1) higher education (bachelor's degree, master's degree or doctoral degree), and (2) less than higher education.

\subsection{Analyses}

Research hypotheses were validated using partial least squares path modeling (PLS-PM). PLS-PM allows one to simultaneously analyze different complex relationships between latent variables, but compared with covariance-based structural equation modeling (CBSEM) it is less restrictive in terms of sample size (Henseler et al., 2009) and does not impose any distributional assumptions on the data (Sanchez, 2013). PLS can be applied in both exploratory and confirmatory research (Chin, 2010). Given the above, the use of PLS was appropriate in this study. The use of PLS included (1) the assessment of the measurement model (essentially confirmatory factor analysis), and then (2) the assessment of the structural model (Hair et al., 2011).

\subsection{Measurement model}

The measurement model only involved constructs with reflective indicators. Validity and reliability tests were conducted to assess the quality of the measurement model. Confirmatory factor analysis showed that factor loadings overcame the critical value of 0.7 (Hair et al.,2019). Moreover, the loadings of the indicators on their respective latent variables were higher than the cross-loadings on other latent variables (see Table 3). Average variance extracted (AVE) was above the 0.5 threshold (Hair et al., 2019). The square root of the AVE was greater than all corresponding correlations (Table 4).

The above results supported convergent and discriminant validity. Unidimensionality for blocks of indicators was examined using Cronbach's alpha, Dillon-Goldstein's rho, and the first and second eigenvalues of the indicators' correlation matrices. The results in Table 3 show that all these statistics met the recommended values; that is, Cronbach's alpha $>0.7$, Dillon-Goldstein's rho $>0.7$, first eigenvalue $>1$ and second eigenvalue $<1$ (Chin, 1998; Sanchez, 2013). Summarizing, the results of the above analysis suggested a good psychometric quality of the measurement model.

\section{Results}

\subsection{The quality of the structural model}

The $R 2$ determination coefficient, the redundancy index, and the goodness of fit $(\mathrm{GoF})$ were investigated to assess the quality of the structural model. The higher the values of these indices, the better the quality of the model. The $R 2$ values ranged from 0.277 for knowledge collecting to 0.692 for idea realization (Table 5). This result means that $\mathrm{R} 2$ values in this model were low $(R 2<0.3)$, moderate $(0.3<R 2<0.6)$, or high $(R 2>0.6$; Sanchez, 2013). The mean redundancy was 0.622 for idea realization, which suggested that other constructs (horizontal and vertical trust, knowledge donating and collecting, and idea generation) predicted $62.2 \%$ of the variability of the idea realization indicators. The general prediction of model performance was assessed using the GoF index (Tenenhaus et al., 2004), which was 0.57. The GoF index was below the suggested cutoff of 0.7 (Sanchez, 2013).

\subsection{Relationships among trust, knowledge sharing, and IWB}

The bootstrap method with 2,000 subsamples was performed to generate $95 \%$ confidence intervals (CIs) and test the statistical significance of the path coefficients. A path coefficient between variables is significant if a CI generated for this estimated coefficient does not
Trust, knowledge sharing, and innovative work behavior

1843 
EJIM

24,5 evaluation results

Table 4.

Descriptive statistics.

Construct correlations and square root of average variance extracted

\begin{tabular}{|c|c|c|c|c|c|c|c|}
\hline $\begin{array}{l}\text { EJIM } \\
24,5\end{array}$ & & $\begin{array}{l}\text { Horizontal } \\
\text { trust (HT) }\end{array}$ & $\begin{array}{l}\text { Vertical } \\
\text { trust (VT) }\end{array}$ & $\begin{array}{c}\text { Knowledge } \\
\text { donating (KD) }\end{array}$ & $\begin{array}{l}\text { Knowledge } \\
\text { collecting } \\
\text { (KC) }\end{array}$ & $\begin{array}{c}\text { Idea } \\
\text { generation } \\
\text { (IG) }\end{array}$ & $\begin{array}{c}\text { Idea } \\
\text { realization } \\
\text { (IR) }\end{array}$ \\
\hline \multirow{25}{*}{1844} & Crossloadings & & & & & & \\
\hline & HT1 & 0.82 & 0.57 & 0.32 & 0.28 & 0.18 & 0.14 \\
\hline & HT2 & 0.89 & 0.63 & 0.41 & 0.46 & 0.25 & 0.21 \\
\hline & HT3 & 0.89 & 0.73 & 0.49 & 0.48 & 0.38 & 0.29 \\
\hline & $\begin{array}{l}\text { VT1 } \\
\text { ? }\end{array}$ & 0.73 & 0.95 & 0.49 & 0.44 & 0.37 & 0.27 \\
\hline & VT2 & 0.71 & 0.94 & 0.46 & 0.45 & 0.33 & 0.24 \\
\hline & VT3 & 0.69 & 0.93 & 0.56 & 0.49 & 0.44 & 0.34 \\
\hline & KD1 & 0.43 & 0.50 & 0.87 & 0.59 & 0.50 & 0.40 \\
\hline & $\mathrm{KD} 2$ & 0.46 & 0.53 & 0.90 & 0.70 & 0.53 & 0.41 \\
\hline & KD3 & 0.43 & 0.43 & 0.88 & 0.60 & 0.47 & 0.38 \\
\hline & $\mathrm{KD} 4$ & 0.37 & 0.41 & 0.83 & 0.61 & 0.47 & 0.37 \\
\hline & $\mathrm{KCl}$ & 0.48 & 0.44 & 0.61 & 0.84 & 0.38 & 0.28 \\
\hline & $\mathrm{KC} 2$ & 0.40 & 0.43 & 0.66 & 0.78 & 0.53 & 0.45 \\
\hline & KC3 & 0.40 & 0.39 & 0.57 & 0.87 & 0.35 & 0.25 \\
\hline & $\mathrm{KC} 4$ & 0.32 & 0.34 & 0.50 & 0.83 & 0.34 & 0.20 \\
\hline & IG1 & 0.31 & 0.39 & 0.54 & 0.49 & 0.88 & 0.64 \\
\hline & IG2 & 0.26 & 0.35 & 0.52 & 0.45 & 0.92 & 0.79 \\
\hline & IG3 & 0.32 & 0.37 & 0.49 & 0.42 & 0.93 & 0.83 \\
\hline & IR1 & 0.21 & 0.27 & 0.44 & 0.37 & 0.80 & 0.95 \\
\hline & IR2 & 0.23 & 0.27 & 0.40 & 0.32 & 0.78 & 0.95 \\
\hline & IR3 & 0.29 & 0.32 & 0.44 & 0.38 & 0.77 & 0.94 \\
\hline & $\begin{array}{l}\text { Cronbach's } \\
\text { alpha }\end{array}$ & 0.83 & 0.93 & 0.89 & 0.85 & 0.90 & 0.94 \\
\hline & $\begin{array}{l}\text { Dillon- } \\
\text { Goldstein's } \\
\text { rho }\end{array}$ & 0.90 & 0.96 & 0.93 & 0.90 & 0.93 & 0.96 \\
\hline & $\begin{array}{l}\text { First } \\
\text { eigenvalue }\end{array}$ & 2.27 & 2.67 & 3.07 & 2.80 & 2.51 & 2.72 \\
\hline & $\begin{array}{l}\text { Second } \\
\text { eigenvalue }\end{array}$ & 0.40 & 0.19 & 0.53 & 0.58 & 0.31 & 0.17 \\
\hline & AVE & 0.75 & 0.89 & 0.76 & 0.69 & 0.83 & 0.90 \\
\hline
\end{tabular}

Measurement model Note(s): The italic elements are the highest values of factor loadings in the row and indicate that an item's loadings on its intended variable are higher than on other variables

\begin{tabular}{|c|c|c|c|c|c|c|c|c|c|}
\hline & Variable & Mean & $\mathrm{SD}$ & 1 & 2 & 3 & 4 & 5 & 6 \\
\hline & Horizontal trust & 5.47 & 1.19 & 0.87 & & & & & \\
\hline 2 & Vertical trust & 5.33 & 1.58 & $0.75^{*}$ & 0.94 & & & & \\
\hline 3 & Knowledge donating & 5.45 & 1.35 & $0.48^{*}$ & $0.53^{*}$ & 0.88 & & & \\
\hline 4 & Knowledge collecting & 5.79 & 1.04 & $0.47 *$ & $0.49 *$ & $0.71 *$ & 0.83 & & \\
\hline 5 & Idea generation & 5.15 & 1.34 & $0.32 *$ & $0.41^{*}$ & $0.57 *$ & $0.50 *$ & 0.92 & \\
\hline 6 & Idea realization & 4.65 & 1.59 & $0.25 *$ & $0.30 *$ & $0.45 *$ & $0.37 *$ & $0.83^{*}$ & 0.9 \\
\hline
\end{tabular}

Note(s): The italic diagonal elements represent the square root of AVE; *correlation is significant at the 0.01 level

contain zero (Henseler et al., 2009). Table 6 gives results of the bootstrap validation. Figure 2 shows the structural model with path coefficients. The results reveal that both types of trust are positively related to knowledge donating and collecting, lending support for H1 and H2. Results also strongly support H5, because the path coefficient between idea generation and idea realization is significant and amounts to 0.85 . As expected in $\mathrm{H6a}$, knowledge donating is 
related to idea generation. The results show an insignificant impact of knowledge donating on idea realization, and of knowledge collecting on both idea generation and idea realization. Thus, H6b, H7a, and H7b are not supported. The results show an insignificant impact of horizontal trust on both idea generation and idea realization, so H10a and H10b are not supported. As expected in H11a, vertical trust is related to idea generation. However, vertical trust does not have a significantly positive effect on idea realization, so H11b is not supported.

In addition to the direct effects of trust on knowledge sharing and innovative work behavior, the indirect effects of horizontal and vertical trust on idea generation and realization through knowledge donating and collecting were investigated (Table 7 and Table 8). The results show that horizontal trust has an insignificant indirect effect on idea generation through knowledge donating (0.07) and collecting (0.05), but a total indirect effect (0.12) is significant. Moreover, horizontal trust has insignificant indirect effects, both total and specific, on idea realization. Vertical trust has a significant indirect effect on idea generation through knowledge donating (0.15), but an insignificant indirect effect on idea generation through knowledge collecting (0.05). A total indirect effect of vertical trust on idea generation is also significant (0.20). Vertical trust has also a significant total indirect effect $(0.31)$ on idea realization, mainly through knowledge donating and idea generation (0.13). These findings partly support H12, but there are no grounds for supporting H13.

Additionally, according to the approach proposed by Baron and Kenny (1986), it was investigated whether idea generation might be a mediator between knowledge donating and idea realization. An alternative structural model without a relationship between idea generation and idea realization was examined. In the alternative model, the path coefficient between knowledge donating and idea realization has increased from 0.01 to 0.34 and is
Trust, knowledge sharing, and innovative work behavior

1845

\begin{tabular}{|c|c|c|c|c|}
\hline Variable & $R^{2}$ & Block Communality & Mean redundancy & \\
\hline Horizontal trust & 0.000 & 0.751 & 0.000 & \\
\hline Vertical trust & 0.000 & 0.891 & 0.000 & \\
\hline Knowledge donating & 0.308 & 0.768 & 0.237 & \\
\hline Knowledge collecting & 0.277 & 0.696 & 0.193 & Table 5. \\
\hline Idea generation & 0.352 & 0.838 & 0.297 & Summary of \\
\hline Idea realization & 0.692 & 0.907 & 0.622 & structural model \\
\hline
\end{tabular}

\begin{tabular}{lllll}
\hline Hypothesis & Suggested effect & $B$ & Bootstrap 95\% CI & Support \\
\hline H1a: Horizontal trust $\rightarrow$ Knowledge donating & + & 0.19 & {$[0.01 ; 0.37] \mathrm{Sig}$} & Yes \\
H1b: Horizontal trust $\rightarrow$ Knowledge collecting & + & 0.27 & {$[0.10 ; 0.44] \mathrm{Sig}$} & Yes \\
H2a: Vertical trust $\rightarrow$ Knowledge donating & + & 0.40 & {$[0.22 ; 0.57] \mathrm{Sig}$} & Yes \\
H2b: Vertical trust $\rightarrow$ Knowledge collecting & + & 0.29 & {$[0.11 ; 0.46] \mathrm{Sig}$} & Yes \\
H5: Idea generation $\rightarrow$ Idea realization & + & 0.86 & {$[0.79 ; 0.92] \mathrm{Sig}$} & Yes \\
H6a: Knowledge donating $\rightarrow$ Idea generation & + & 0.39 & {$[0.16 ; 0.61] \mathrm{Sig}$} & Yes \\
H6b: Knowledge donating $\rightarrow$ Idea realization & + & 0.01 & {$[-0.11 ; 0.11] \mathrm{Nsig}$} & No \\
H7a: Knowledge collecting $\rightarrow$ Idea generation & + & 0.17 & {$[-0.02 ; 0.37] \mathrm{NSig}$} & No \\
H7b: Knowledge collecting $\rightarrow$ Idea realization & + & -0.05 & {$[-0.13 ; 0.04] \mathrm{Nsig}$} & No \\
H10a: Horizontal trust $\rightarrow$ Idea generation & + & -0.07 & {$[-0.25 ; 0.08] \mathrm{Nsig}$} & No \\
H10b: Horizontal trust $\rightarrow$ Idea realization & + & 0.04 & {$[-0.08 ; 0.18] \mathrm{Nsig}$} & No \\
H11a: Vertical trust $\rightarrow$ Idea generation & + & 0.17 & {$[0.01 ; 0.35] \mathrm{Sig}$} & Yes \\
H11a: Vertical trust $\rightarrow$ Idea realization & + & -0.06 & {$[-0.18 ; 0.05] \mathrm{Nsig}$} & No
\end{tabular}

Note(s): Sig. denotes a significant direct effect at 0.05; Nsig. denotes a non-significant direct effect at 0.05 . Bootstrapping based on $n=2000$ subsamples

Table 6. Structural model results 
EJIM
24,5

1846

Figure 2.

Results of

structural model

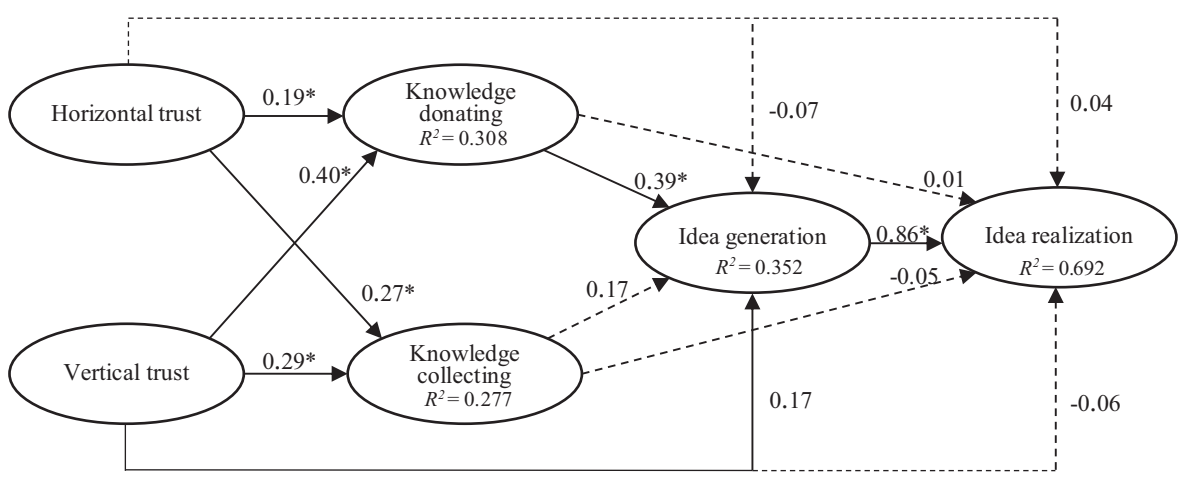

Note(s): $* p<0.05$. The dotted line shows that the coefficient was not significant

Predictor/dependent Knowledge donating $\quad$ Knowledge collecting $\quad$ Idea generation $\quad$ Idea realization

Direct effects

Horizontal trust

$0.19 * \quad 0.27 *$

Vertical trust

$0.40 *$

$0.29 *$

-0.07
$0.17 *$
$0.39 *$

0.04

Knowledge donating

0.17

$-0.06$

Knowledge collecting

Idea generation

$-0.05$

Total indirect effects

Horizontal trust

$0.12^{*}$

$0.20 *$

0.03

Vertical trust

$0.20^{*} \quad 0.31 *$

Knowledge donating

$0.34 *$

Knowledge collecting

0.15

Total effects

Horizontal trust

$0.19 *$

$0.27 *$

$0.29 *$

0.05

0.07

Vertical trust

$0.40^{*}$

$0.37 *$

$0.26 *$

Knowledge donating

0.17

$0.34 *$

Knowledge collecting

Table 7.

Idea generation

0.10

Note(s): *Significance at the 5\% level

Table 8.

Specific indirect effects analysis

\begin{tabular}{lccc}
\hline & Indirect effects & $t$ statistics & $p$ values \\
\hline Horizontal trust $\rightarrow$ Knowledge collecting $\rightarrow$ Idea generation & 0.046 & 1.323 & 0.187 \\
Vertical trust $\rightarrow$ Knowledge collecting $\rightarrow$ Idea generation & 0.049 & 1.332 & 0.184 \\
Horizontal trust $\rightarrow$ Knowledge donating $\rightarrow$ Idea generation & 0.074 & 1.666 & 0.096 \\
Vertical trust $\rightarrow$ Knowledge donating $\rightarrow$ Idea generation & 0.155 & 2.314 & 0.021 \\
Horizontal trust $\rightarrow$ Knowledge collecting $\rightarrow$ Idea realization & -0.013 & 1.016 & 0.310 \\
Vertical trust $\rightarrow$ Knowledge collecting $\rightarrow$ Idea realization & -0.014 & 0.997 & 0.319 \\
Horizontal trust $\rightarrow$ Knowledge donating $\rightarrow$ Idea realization & 0.002 & 0.132 & 0.895 \\
Vertical trust $\rightarrow$ Knowledge donating $\rightarrow$ Idea realization & 0.003 & 0.164 & 0.870 \\
\hline
\end{tabular}




\begin{tabular}{|c|c|c|c|c|c|c|c|c|c|}
\hline \multirow[b]{2}{*}{ Path } & \multicolumn{2}{|c|}{$\begin{array}{l}\text { Higher education } \\
\quad n=202\end{array}$} & \multicolumn{2}{|c|}{$\begin{array}{l}\text { Less than higher } \\
\text { education } n=50\end{array}$} & \multirow[b]{2}{*}{ Diff.abs } & \multicolumn{3}{|c|}{ Bootstrap $t$-test } & \multirow{2}{*}{$\begin{array}{r}\text { Trust, knowledge } \\
\text { sharing, and } \\
\text { innovative work } \\
\text { behavior }\end{array}$} \\
\hline & $\begin{array}{l}\text { Direct } \\
\text { effect }\end{array}$ & Sig.05 & $\begin{array}{l}\text { Direct } \\
\text { effect }\end{array}$ & Sig.05 & & $t$ & $\begin{array}{c}p \\
\text { value }\end{array}$ & Sig.05 & \\
\hline $\begin{array}{l}\text { Horizontal trust } \rightarrow \text { Idea } \\
\text { generation }\end{array}$ & -0.022 & no & -0.235 & no & 0.213 & 0.995 & 0.321 & no & \\
\hline $\begin{array}{l}\text { Horizontal trust } \rightarrow \text { Idea } \\
\text { realization }\end{array}$ & 0.023 & no & 0.157 & no & -0.134 & 0.750 & 0.454 & no & 1847 \\
\hline $\begin{array}{l}\text { Horizontal trust } \rightarrow \\
\text { Knowledge collecting }\end{array}$ & 0.325 & yes & -0.070 & no & 0.395 & 1.862 & 0.064 & no & \\
\hline $\begin{array}{l}\text { Horizontal trust } \rightarrow \\
\text { Knowledge donating }\end{array}$ & 0.218 & yes & -0.041 & no & 0.259 & 1.100 & 0.272 & no & \\
\hline $\begin{array}{l}\text { Idea generation } \rightarrow \text { Idea } \\
\text { realization }\end{array}$ & 0.826 & yes & 0.934 & yes & -0.109 & 1.214 & 0.226 & no & \\
\hline $\begin{array}{l}\text { Knowledge collecting } \rightarrow \\
\text { Idea generation }\end{array}$ & 0.112 & no & 0.198 & no & -0.086 & 0.351 & 0.726 & no & \\
\hline $\begin{array}{l}\text { Knowledge collecting } \rightarrow \\
\text { Idea realization }\end{array}$ & -0.048 & no & 0.063 & no & -0.111 & 1.004 & 0.316 & no & \\
\hline $\begin{array}{l}\text { Knowledge donating } \rightarrow \\
\text { Idea generation }\end{array}$ & 0.367 & yes & 0.552 & yes & -0.185 & 0.664 & 0.507 & no & \\
\hline $\begin{array}{l}\text { Knowledge donating } \rightarrow \\
\text { Idea realization }\end{array}$ & 0.007 & no & -0.030 & no & 0.038 & 0.277 & 0.782 & no & \\
\hline $\begin{array}{l}\text { Vertical trust } \rightarrow \text { Idea } \\
\text { generation }\end{array}$ & 0.130 & no & 0.234 & no & -0.104 & 0.450 & 0.653 & no & \\
\hline $\begin{array}{l}\text { Vertical trust } \rightarrow \text { Idea } \\
\text { realization }\end{array}$ & -0.043 & no & -0.156 & no & 0.113 & 0.721 & 0.472 & no & \\
\hline $\begin{array}{l}\text { Vertical trust } \rightarrow \\
\text { Knowledge collecting }\end{array}$ & 0.192 & no & 0.710 & yes & -0.519 & 2.492 & 0.013 & yes & \\
\hline $\begin{array}{l}\text { Vertical trust } \rightarrow \\
\text { Knowledge donating }\end{array}$ & 0.314 & yes & 0.764 & yes & -0.451 & 2.152 & 0.032 & yes & $\begin{array}{r}\text { Comparing groups by } \\
\text { education level: }\end{array}$ \\
\hline Note(s): Sig.05 - signific & at the $5^{\circ}$ & level; d & $\mathrm{bs}$ - the & solute c & ference 0 & oath c & cients & & bootstrap $t$-test \\
\hline
\end{tabular}

significant. Therefore, the effect of knowledge donating on idea realization is completely mediated by idea generation. However, such a mediating effect of idea generation was not found in the relationship between knowledge collecting and idea realization.

\subsection{Difference between the strengths of the relationships}

To test the remaining hypotheses (H3, H4, H8, and H9), the overlap of the relevant CIs was analyzed. According to the very conservative rule, two parameters are significantly different if their CIs do not overlap (see Cumming, 2009). Cummings (2009) proposed a less restrictive approach: two path coefficients are significantly different if the corresponding 95 percent CIs overlap with no more than 50 percent of the length of a single arm of a CI, "in other words the overlap of the 95 per cent CIs is no more than about half the average arm length, meaning the average of the two arms that overlap" (Cumming, 2009, p. 219). The calculations conducted for path coefficients showed that the appropriate confidence intervals overlapped by more than $50 \%$. Therefore, there is no statistically significant difference between the strengths of the relationships indicated in hypotheses $\mathrm{H} 3, \mathrm{H} 4, \mathrm{H} 8$ and $\mathrm{H} 9$. Hence, there are no grounds for supporting $\mathrm{H} 3$ and $\mathrm{H} 4$ and rejecting $\mathrm{H} 8$ and $\mathrm{H} 9$.

\subsection{Impact of education}

The study investigated if education level impacts the relationships between constructs. The bootstrap $t$-test was applied. Results showed that at the 5 percent level there were 
EJIM

24,5

1848

significantly stronger relationships between vertical trust and knowledge collecting and donating among respondents with less than higher education compared to respondents with higher education (Table 9). The study next investigated if mean values for constructs are different for respondents with higher education and respondents with less than higher education. The Mann-Whitney $U$ test was applied. The mean values of horizontal trust, knowledge collecting $(p<0.05)$, vertical trust and knowledge donating $(\phi<0.1)$ were significantly higher for respondents with higher education than for respondents with less than higher education.

\section{Discussion}

The purpose of this paper is to assess the effects of two types of trust (vertical and horizontal trust) on knowledge sharing (knowledge donating and knowledge collecting) and the impact of knowledge sharing on innovative work behavior (idea generation and idea realization). This topic was investigated in the context of white-collar employees from a large Polish organization.

\subsection{Relationships between trust and knowledge sharing}

The study shows that both vertical trust and horizontal trust are related to knowledge donating and knowledge collecting. This finding is consistent with prior studies, which claimed that trust is an important determinant of knowledge sharing (Hsu and Chang, 2014; Renzl, 2008; Staples and Webster, 2008). However, the present study examined this relationship in more detail.

\subsection{Which trust is more strongly related to knowledge sharing}

The values of the path coefficients suggested that vertical trust $(B=0.40)$ might be more strongly related to knowledge donating than horizontal trust is $(B=0.19)$. However, further analysis indicated that the difference between these two path coefficients was not statistically significant. Moreover, the strength of the relationship between vertical trust and knowledge collecting and the strength of the relationship between horizontal trust and knowledge collecting are very similar ( 0.29 vs. 0.27$)$. The above results indicate that vertical trust and horizontal trust have a similar positive effect on knowledge sharing in the workplace.

This finding is inconsistent with a study conducted by Wu et al. (2009). The authors claimed that trust of colleagues plays a more important role for knowledge sharing than trust of supervisors. This inconsistency may have several causes. First, although one coefficient might be greater than the other coefficient, the difference may not be statistically significant. Wu et al. (2009) did not report empirical evidence that the difference between the coefficient (beta weight) for the relation between trust of colleagues and knowledge sharing and the coefficient for the relation between trust of supervisors and knowledge sharing was statistically significant. This lack of evidence suggests that conclusions about which relationship was stronger were based on simplified assumptions. Such simplistic inferences are also observed in other studies (for example, Le and Lei, 2018; Spanuth and Wald, 2017). If such simplistic inferences are applied in the present study, then vertical trust is more strongly related with knowledge sharing, especially with knowledge donating.

Second, cultural context may decide which type of trust, vertical or horizontal, has a greater impact on knowledge sharing behaviors. Studies conducted in Taiwan (Wu et al., 2009) and Australia (Lee et al., 2010) suggested that horizontal trust is more strongly related to knowledge sharing. Compared to Taiwan and Australia, however, in Poland, employees are less prone to risk, avoid uncertainty and more often expect clear instructions from their supervisors (Insights, 2018). Under such conditions, trust in a superior can be at least as 
important as trust in colleagues in the context of knowledge sharing behaviors at the workplace.

This study reveals that trust in a superior is significantly more strongly related to knowledge sharing among employees with less than a higher education compared to employees with a higher education. This result may occur because employees with a higher education usually are more self-confident, know their value, and have a greater ability to meet the requirements of colleagues in the field of knowledge (Le and Lei, 2018). Trust in their superior is important in order to share knowledge, but not so important as it is for employees with less education.
Trust, knowledge sharing, and innovative work behavior

1849

\subsection{Relationships between knowledge sharing and IWB}

This study offered an alternative to traditional studies, which were mainly concentrated on the effect of knowledge sharing on innovative work behavior, without examining relationships between components of knowledge sharing and components of innovative work behavior. Although this study confirms previous empirical studies that proved that knowledge sharing supports IWB (Akram et al., 2018; Kim and Park, 2017; Mura et al., 2013; Radaelli et al., 2014), it also provides some interesting results. As expected, knowledge donating is positively related to idea generation, but, contrary to expectations, the relation between knowledge collecting and idea generation is not significant. This finding is partly inconsistent with a previous study that suggested that both knowledge outflows from and knowledge inflows into the business unit affect employee innovative behavior (Lai et al., 2016). The lack of a significant relationship between knowledge collecting and idea generation can be explained by the phenomenon of homogeneous knowledge collected by employees. It should be noted that the scale for knowledge collecting used in this study concerned only the collection of knowledge from colleagues. Employees who collect knowledge from colleagues also collect their ideas. It may be said that the greater the knowledge collecting by employees from other employees, the more uniform knowledge will be among employees, which hinders the generation of new, innovative ideas. Zhang et al. (2019) drew attention to the difficulty of generating ideas under the conditions of homogeneous knowledge. Previous studies have confirmed the positive relationship between heterogeneity of knowledge and creativity (Huang and Liu, 2015) and innovativeness (Rodan and Galunic, 2004). It was also found that groups composed of members who were heterogeneous in their knowledge structure generate more ideas than groups composed of members who were homogeneous with regard to their knowledge (Stroebe and Diehl, 1994). Therefore, it can be concluded that merely collecting knowledge from colleagues is not sufficient for generating new ideas. It is also important to collect heterogeneous knowledge from various sources, the ability to process collected knowledge, as well as divergent and independent thinking.

A significant relationship between knowledge donating and idea generation is also interesting in the context of findings of Axtell et al. (2000). According to Axtell et al. (2000), idea generation depends more on individual characteristics, while idea realization is rather a team activity. Similarly, Liua and Phillips (2011) stated that implementing innovation depends on cooperation between employees and combining their knowledge and skills. Therefore, it would seem that knowledge donating, which is a social activity, will be stronger related to idea realization than with idea generation. Nevertheless, the results of this research do not confirm this reasoning. This can be explained by the fact that knowledge donating requires selfconfidence and job knowledge, that is the same characteristics of the individual that are useful in the idea generation process (Axtell et al., 2000). Thus, there is no contradiction between social activity (knowledge donating) and individual activity (idea generation). It is more justified to say that social activity strengthens individual activity in the area of idea generation.

Surprisingly, this study does not provide evidence that knowledge donating or knowledge collecting are directly related to idea realization. Based on such outcomes, it can be 
EJIM

24,5

1850

controversially claimed that innovativeness, as real actions in organizations, does not exist as the result of trust and knowledge sharing. More building of vertical and horizontal trust and speeding up of knowledge donating only increases the level of ideas, but ideas are not the same as innovativeness of organizations. Such a claim is consistent with some previous research conducted in Polish companies, which found no direct relationships between knowledge sharing and a firm's innovativeness (Kmieciak and Michna, 2018). Nevertheless, the mediation analysis indicates an indirect impact of knowledge donating on idea realization, via idea generation. In the present study, idea generation is strongly related to idea realization. This result supports previous claims that innovation is a multi-stage process, that idea generation is followed by idea realization (De Jong and Den Hartog, 2010; Krause, 2004; Spanuth and Wald, 2017), and that stages of the innovation process are highly correlated (and therefore some scholars treat innovative behavior as one construct).

\subsection{Which knowledge sharing behavior is more strongly related to IWB}

The present study suggests that knowledge donating is more important for idea generation than knowledge collecting. This finding is explained by the positions of a knowledge sender and receiver. As is commonly known, knowledge is a crucial ingredient in innovation processes (Plessis, 2007). A receiver of knowledge plays the role of a student who has a knowledge deficiency. Only when a receiver gathers and updates his or her own knowledge will he or she be able to offer innovative solutions. However, if knowledge collecting is not accompanied by knowledge donating, a knowledge receiver is perceived as a knowledge parasite; that is a greedy and unfair person in the conditions of competition between employees within the organization (Lai et al., 2016). This negatively affects the willingness of other people to share valuable and relevant knowledge with such a person, which worsens his/her potential for idea generation. On the other hand, a knowledge sender plays the role of a teacher who has appropriate knowledge and passes this knowledge to others. Hence, a knowledge sender already has knowledge. Moreover, when sharing one's own knowledge, a self-learning mechanism appears (Lai et al., 2016) and the sender has an opportunity to update and recombine the knowledge. Consequently, the knowledge is likely to appear as new knowledge, which can trigger new ideas. Hence, a knowledge sender is more likely to generate innovative ideas faster than a knowledge receiver.

\subsection{Relationships between trust and IWB}

This study is consistent with previous studies assuming the relationship between trust in the workplace and innovative behavior (Barczak et al., 2010; Yu et al., 2018). However, the present analyzed this relationship in more detail. It turned out that a direct relationship exists only between vertical trust and idea generation. Moreover, unlike horizontal trust, vertical trust not only has a direct influence on the idea generation, but also indirectly influences it through knowledge donating. These results are inconsistent with the results of the research carried out in a major Dutch financial services firm, which indicated that, for the relationship between innovative behavior and team performance, the most favorable situation is when horizontal trust is high and vertical trust is low (Hughes et al., 2018). Cultural factors may have influenced the results obtained. In Poland, people are generally very cautious about unconventional behaviors and ideas and are reluctant to take risks (Insights, 2018). For fear of a negative reaction from their superior, they may refrain from proposing innovative solutions. In such conditions, trust in the supervisor is more important than trust in coworkers, because it is mainly the supervisor who determines the sense of security of the subordinate. With high vertical trust, employees' fears of criticism, ridicule, or even punishment for bad ideas are reduced. 


\subsection{Theoretical implications}

This study contributes to understanding the processes of trust and knowledge sharing, and their impact on innovative behavior. Previous research exists on the relationship between trust and knowledge sharing (Rutten et al.,2016), but this study distinguishes between two types of trust and two types of knowledge sharing behaviors. Such an approach is relatively new in the literature; it was used by Le and Lei (2018), who called for further research in this field in other contexts. Hence, this research responds to this call. Thanks to the analysis of specific manifestations of trust and knowledge sharing, the results of the study reveal that vertical trust is more important for knowledge donating than horizontal trust, while vertical trust and horizontal trust have similar impacts on knowledge collecting.

In addition, this study extends the research model for IWB. Although the literature suggests that various knowledge sharing behaviors may have different antecedents and implications (Mura et al., 2013; Le and Lei, 2018), empirical research on relationships between knowledge donating and collecting on the one side, and idea generation and realization on the other side have been virtually non-existent. The present study indicates that knowledge donating is more important for idea generation than knowledge collecting. Moreover, little has been known about whether and how knowledge sharing mediates the link between trust and IWB. The present study reveals that knowledge donating mediates the relationships between vertical trust and idea generation. Such mediating effect has not been observed in the case of knowledge collecting. Finally, it was not previously clear whether trust and knowledge sharing have direct impact on idea realization. While this study shows no such direct relationships, it does indicate that idea generation plays the role of mediator between knowledge donating and idea realization.

\subsection{Practical implications}

The study highlights the importance of trust and knowledge donating behavior for individual innovativeness. If managers want to improve employees' innovative behavior, they should build trust in an organization, particularly vertical trust and create conditions for knowledge sharing, in particular knowledge donating. Hence, managers should not only encourage employees to collect the knowledge needed to innovate, but also encourage them to donate knowledge to others.

Managers can stimulate knowledge sharing among employees using means such as giving employees new challenges, encouraging employees to try new approaches, initiating processes aimed at developing knowledge and sharing experience and expertise (for example, by mentoring or coaching; Lee et al., 2010). Particularly valuable to knowledge sharing may be mentoring (Bryant and Terborg, 2008), including intermentoring. Intermentoring includes the two-way transfer of knowledge between employees; that is, the mentor is also the student and the student is also the mentor, in a specific expertise area. This type of mentoring provides balance between knowledge donating and collecting and creates conditions for a fuller use of the knowledge and skills embedded in employees. Intermentoring is expected to increase employees' self-esteem and bonds between employees (Michna et al., 2018). A welldesigned motivational system should encourage employees to share knowledge and participate in mentoring initiatives.

Encouraging knowledge donating means supporting the self-learning mechanisms that occur when knowledge is shared. A knowledge sender should be encouraged to reflect on his or her knowledge and to question previous beliefs and assumptions. Such critical reflection leads to rejecting obsolete knowledge through unlearning (Matsuo, 2018), which releases creativity (Cegarra-Navarro et al., 2010).
Trust, knowledge sharing, and innovative work behavior

1851 
EJIM

24,5

1852

Knowledge sharing by employees can be supported by building trust in the organization. The relationship between vertical trust and knowledge sharing is especially strong among respondents with a less than higher education. Such employees might feel unconfident compared to employees with a higher education, and therefore they need particular support from their supervisors to share knowledge. Building trust among supervisors and employees requires the creation of an organizational culture where individuals treat each other fairly and honestly, help each other in solving complex problems, and are not afraid to express their frustration, opinions, personal beliefs and feelings, positive as well as negative (Le and Lei, 2018). Training and team building exercises can help employees and supervisors understand how they can contribute to a positive work climate and avoid actions that undermine the trust of their coworkers (Lee et al., 2010), and should be considered.

\subsection{Limitations and suggestions for further research}

The present study has limitations which may be overcome in future research. First, the measurement of variables was based on self-reports and was conducted at one point in time, which increases the threat that a common method bias influenced the research results. Although some remedies were applied to minimize the potential effects of bias on the findings (e.g., the anonymity and confidentiality of the respondents was ensured), and a Harman single factor test showed that the bias was not a problem in this study, in future research, collecting data from different sources is recommended. For example, the employee's innovative behavior may be assessed by the supervisor or using objective data, if available. Second, this study, like many previous studies, assumes that trust has an impact on knowledge sharing. However, future studies should consider a reciprocal effect; that is, to what extent knowledge sharing increases trust among colleagues. Third, this study is cross-sectional. A longitudinal study would be more appropriate to prove causal relationships between trust, knowledge sharing, and innovative behavior. Fourth, in this study only two types of trust were analyzed, vertical and horizontal trust. However, within these two types of trust, a reliance-based trust and disclosure-based trust can be distinguished (see Le and Lei, 2018). Fifth, the study was conducted in one large capital group in Poland. Some results, for example, the result regarding which type of trust is more important for knowledge sharing, may depend on the cultural context. Therefore, the generalizability of the findings is limited. Future research in different countries and industries will help address this concern. Finally, high levels of trust (vertical and horizontal) may reduce the control of knowledge donating and collecting, leading to the spread of poor-quality knowledge. Therefore, it would be wise in the next research to test mediating role of knowledge quality.

\section{Conclusion}

This study investigated relationships between trust, knowledge sharing, and innovative behavior in the workplace. Contrary to many previous studies, this study distinguished between types of trust (vertical and horizontal) and types of knowledge sharing behaviors (donating and collecting), as well as between types of innovative behaviors (idea generation and idea realization). Therefore, the results of this study enable managers to better understand what factors and processes contribute to greater IWB. Idea generation is stimulated by knowledge donating, which is, in turn, supported by vertical and horizontal trust. Hence, managers should create a climate of trust; this is particularly important for knowledge sharing behaviors among less-educated employees. Moreover, conditions for employees' knowledge donating, which is more strongly related to IWB than knowledge collecting, should be developed with due attention in organizations. 


\section{References}

Abdelwhab Ali, A., Panneer selvam, D.D.D., Paris, L. and Gunasekaran, A. (2019), "Key factors influencing knowledge sharing practices and its relationship with organizational performance within the oil and gas industry", Journal of Knowledge Management, Vol. 23 No. 9, pp. 1806-1837.

Afsar, B., Al-Ghazali, B.M., Cheema, S. and Javed, F. (2020), "Cultural intelligence and innovative work behavior: the role of work engagement and interpersonal trust", ahead-of-print No. ahead-ofprint, European Journal of Innovation Management. doi: 10.1108/EJIM-01-2020-0008.

Ahteela, R. and Vanhala, M. (2018), "HRM bundles and organizational trust", Knowledge and Process Management, Vol. 25 No. 1, pp. 3-11.

Akram, T., Lei, S., Haider, M.J. and Hussain, S.T. (2018), "Exploring the impact of knowledge sharing on the innovative work behavior of employees: a study in China", International Business Research, Vol. 11 No. 3, pp. 186-194.

Al-Alawi, A.I., Al-Marzooqi, N.Y. and Mohammed, Y.F. (2007), "Organizational culture and knowledge sharing: critical success factors", Journal of Knowledge Management, Vol. 11 No. 2, pp. 22-42.

Amayah, A.T. (2013), "Determinants of knowledge sharing in a public sector organization", Journal of Knowledge Management, Vol. 17 No. 3, pp. 454-471.

Anser, M.K., Yousaf, Z., Khan, A. and Usman, M. (2020), "Towards innovative work behavior through knowledge management infrastructure capabilities: mediating role of functional flexibility and knowledge sharing", ahead-of-print No. ahead-of-print, European Journal of Innovation Management. doi: 10.1108/EJIM-09-2019-0250.

Axtell, C.M., Holman, D.J., Unsworth, K.L., Wall, T.D., Waterson, P.E. and Harrington, E. (2000), "Shopfloor innovation: facilitating the suggestion and implementation of ideas", Journal of Occupational and Organizational Psychology, Vol. 73 No. 3, pp. 265-286.

Bakker, M., Leenders, R.T.A.J., Gabbay, S.M., Kratzer, J. and Engelen, J.M.L.V. (2006), "Is trust really social capital? Knowledge sharing in product development projects", The Learning Organization, Vol. 13 No. 6, pp. 594-605.

Bantel, K. and Jackson, S. (1989), "Top management and innovations in banking: does the composition of the top team make a difference?”, Strategic Management Journal, Vol. 10, pp. 107-124.

Barczak, G., Lassk, F. and Mulki, J. (2010), "Antecedents of team creativity: an examination of team emotional intelligence, team trust and collaborative culture", Creativity and Innovation Management, Vol. 19 No. 4, pp. 332-345.

Baron, R.M. and Kenny, D.A. (1986), "The moderator-mediator variable distinction in social psychological research: conceptual, strategic and statistical considerations", Journal of Personality and Social Psychology, Vol. 51 No. 6, pp. 1173-1182.

Bhattacharya, R., Devinney, T.M. and Pillutla, M.M. (1998), "A formal model of trust based on outcomes", Academy of Management Review, Vol. 23 No. 3, pp. 459-472.

Boon, S. and Holmes, J.G. (1991), "The dynamics of interpersonal trust: resolving uncertainty in the face of risk", in Hinde, R.A. and Groebel, J. (Eds), Cooperation and Prosocial Behaviour, Cambridge University Press, Cambridge, pp. 190-211.

Brislin, R.W. (1986), "The wording and translation of research instruments", in Lonner, W.J. and Berry, J.W. (Eds), Field Methods in Cross-Cultural Research, Sage, Thousand Oaks, CA, pp. 137-164.

Bryant, S.E. and Terborg, J.R. (2008), "Impact of peer mentor training on creating and sharing organizational knowledge", Journal of Managerial Issues, Vol. 20 No. 1, pp. 11-29.

Casimir, G., Lee, K. and Loon, M. (2012), "Knowledge sharing: influences of trust, commitment and cost", Journal of Knowledge Management, Vol. 16 No. 5, pp. 740-753.

Cegarra-Navarro, J.G., Cepeda-Carrion, G. and Jimenez-Jimenez, D. (2010), "Linking unlearning with innovation through organizational memory and technology", Electronic Journal of Knowledge Management, Vol. 8 No. 1, pp. 1-10.
Trust, knowledge sharing, and innovative work behavior 
EJIM

24,5

1854

Charron, N. and Rothstein, B. (2016), "Does education lead to higher generalized trust? The importance of quality of government", International Journal of Educational Development, Vol. 50, pp. 59-73.

Chen, C.J. and Hung, S.W. (2010), "To give or to receive? Factors influencing members' knowledge sharing and community promotion in professional virtual communities", Information and Management, Vol. 47 No. 4, pp. 226-236.

Chen, C.-J., Huang, J.W.W. and Hsiao, Y.-C. (2010), "Knowledge management and innovativeness. The role of organizational climate and structure", International Journal of Manpower, Vol. 31 No. 8, pp. 848-870.

Chin, W.W. (1998), "The partial least squares approach to structural equation modeling", in Marcoulides, G.A. (Ed.), Modern Methods for Business Research, Lawrence Erlbaum Associates, Mahwah, NJ, pp. 295-336.

Chin, W.W. (2010), "How to write up and report PLS analyses", in Esposito Vinzi, V., Chin, W.W., Henseler, J. and Wang, H. (Eds), Handbook of Partial Least Squares: Concepts, Methods and Applications, Springer, Berlin, pp. 655-690.

Choi, S.Y., Lee, H. and Yoo, Y. (2010), "The impact of information technology and transactive memory systems on knowledge sharing, application, and team performance: a field study", MIS Quarterly, Vol. 34 No. 4, pp. 855-870.

Chow, W.S. and Chan, L.S. (2008), "Social network, social trust and shared goals in organizational knowledge sharing", Information and Management, Vol. 45 No. 7, pp. 458-465.

Colquitt, J.A., Scott, B.A. and LePine, J.A. (2007), “Trust, trustworthiness, and trust propensity: a metaanalytic test of their unique relationships with risk taking and job performance", Journal of Applied Psychology, Vol. 92 No. 4, pp. 909-927.

Cropanzano, R. and Mitchell, M.S. (2005), "Social exchange theory: an interdisciplinary review", Journal of Management, Vol. 31 No. 6, pp. 874-900.

Cumming, G. (2009), "Inference by eye: reading the overlap of independent confidence intervals", Statistics in Medicine, Vol. 28 No. 2, pp. 205-220.

Curado, C. and Vieira, S. (2019), "Trust, knowledge sharing and organizational commitment in SMEs", Personnel Review, Vol. 48 No. 6, pp. 1449-1468.

Das, T. and Teng, B. (1998), "Between trust and control: developing confidence in partner cooperation in alliances", Academy of Management Review, Vol. 23 No. 3, pp. 491-512.

De Jong, J. and Den Hartog, D. (2010), "Measuring innovative work behavior", Creativity and Innovation Management, Vol. 19 No. 1, pp. 23-36.

De Jong, B.A., Dirks, K.T. and Gillespie, N. (2016), “Trust and team performance: a meta-analysis of main effects, moderators, and covariates", Journal of Applied Psychology, Vol. 101 No. 8, pp. 1134-1150.

de Vries, R.E., van den Hooff, B. and de Ridder, J.A. (2006), "Explaining knowledge sharing: the role of team communication styles, job satisfaction, and performance beliefs", Communication Research, Vol. 33 No. 2, pp. 115-135.

Dirks, K.T. and Ferrin, D.L. (2002), "Trust in leadership: meta-analytic findings and implications for research and practice", Journal of Applied Psychology, Vol. 87 No. 4, pp. 611-628.

Dorenbosch, L., van Engen, M. and Verhagen, M. (2005), "On-the-job innovation: the impact of job design and human resource management through production ownership", Creativity and Innovation Management, Vol. 14 No. 2, pp. 129-141.

Durst, S. and Runar, E.I. (2012), "Knowledge management in SMEs: a literature review", Journal of Knowledge Management, Vol. 16 No. 6, pp. 879-903.

Erkutlu, H. and Chafra, J. (2015), "The mediating roles of psychological safety and employee voice on the relationship between conflict management styles and organizational identification", American Journal of Business, Vol. 30 No. 1, pp. 72-91.

Faul, F., Erdfelder, E., Buchner, A. and Lang, A.-G. (2009), "Statistical power analyses using G*Power 3.1: tests for correlation and regression analyses", Behavior Research Methods, Vol. 41 No. 4, pp. 1149-1160. 
Feitosa, J., Grossman, R., Kramer, W.S. and Salas, E. (2020), "Measuring team trust: a critical and meta-analytical review", Journal of Organizational Behavior, Vol. 41 No. 5, pp. 479-501.

Guinot, J., Chiva, R. and Roca-Puig, V. (2014), "Interpersonal trust, stress and satisfaction at work: an empirical study", Personnel Review, Vol. 43 No. 1, pp. 96-115.

Hair, J.F., Ringle, C.M. and Sarstedt, M. (2011), "PLS-SEM: indeed a silver bullet", Journal of Marketing Theory and Practice, Vol. 19 No. 2, pp. 139-152.

Hair, J.F., Risher, J.J., Sarstedt, M. and Ringle, C.M. (2019), "When to use and how to report the results of PLS-SEM", European Business Review, Vol. 31 No. 1, pp. 2-24.

Hanif, A. and Bukhari, I. (2015), "Relationship between innovative work behavior and job involvement among the employees of telecom sector", Pakistan Journal of Social and Clinical Psychology, Vol. 13 No. 2, pp. 23-29.

Henseler, J., Ringle, C.M. and Sinkovics, R.R. (2009), "The use of Partial Least Squares path modeling in international marketing", in Sinkovics, R.R. and Ghauri, P.N. (Eds), New Challenges to International Marketing (Advances in International Marketing, Emerald, Bingley, Vol. 20, pp. 277-320.

Hooghe, M., Marien, S. and de Vroome, T. (2012), "The cognitive basis of trust. The relation between education, cognitive ability, and generalized and political trust", Intelligence, Vol. 40 No. 6, pp. 604-613.

Hsu, M.H. and Chang, C.M. (2014), "Examining interpersonal trust as a facilitator and uncertainty as an inhibitor of intra-organisational knowledge sharing", Information Systems Journal, Vol. 24 No. 2, pp. 119-142.

Huang, C.-E. and Liu, C.-H.S. (2015), "Employees and creativity: social ties and access to heterogeneous knowledge”, Creativity Research Journal, Vol. 27 No. 2, pp. 206-213.

Hughes, M., Rigtering, J.P.C., Covin, J.G., Bouncken, R.B. and Kraus, S. (2018), "Innovative behaviour, trust and perceived workplace performance", British Journal of Management, Vol. 29 No. 4, pp. $750-768$.

Hutchinson, V. and Quintas, P. (2008), "Do SMEs do knowledge management? Or simply manage what they know?”, International Small Business Journal, Vol. 26 No. 2, pp. 131-134.

Insights, H. (2018), “Compare countries”, available at: https://www.hofstede-insights.com/product/ compare-countries/ (accessed 10 October 2018).

Janssen, O. (2000), "Job demands, perceptions of effort-reward fairness, and innovative work behavior", Journal of Occupational and Organizational Psychology, Vol. 73 No. 3, pp. 287-302.

Khorakian, A., Mohammadi Shahroodi, H., Jahangir, M. and Nikkhah Farkhani, Z. (2019), "Innovative work behavior in public organizations: the roles of ethical and knowledge sharing behaviors", Creativity Research Journal, Vol. 31 No. 2, pp. 164-173.

Kim, W. and Park, J. (2017), "Examining structural relationships between work engagement, organizational procedural justice, knowledge sharing, and innovative work behavior for sustainable organizations", Sustainability, Vol. 9 No. 2, pp. 205-220.

Kim, T.Y., Wang, J. and Chen, J. (2018), "Mutual trust between leader and subordinate and employee outcomes", Journal of Business Ethics, Vol. 149 No. 4, pp. 945-958.

Kmieciak, R. and Michna, A. (2018), "Knowledge management orientation, innovativeness, and competitive intensity: evidence from Polish SMEs", Knowledge Management Research and Practice, Vol. 16 No. 4, pp. 559-572.

Krause, D.E. (2004), "Influence-based leadership as a determinant of the inclination to innovate and of innovation-related behaviors: an empirical investigation”, Leadership Quarterly, Vol. 15 No. 1, pp. 79-102.

Kucharska, W. and Kowalczyk, R. (2016a), "Tacit knowledge sharing and creativity: how to derive innovation from project teams?", in Proceedings of the European Conference on Innovation and Entrepreneurship, pp. 444-452.

Kucharska, W. and Kowalczyk, R. (2016b), "Trust, collaborative culture and tacit knowledge sharing in project management: a relationship model", in Proceedings of the 13th International
Trust, knowledge sharing, and innovative work behavior

1855 
EJIM 24,5

1856

Conference on Intellectual Capital, Knowledge Management and Organisational Learning, ICICKM 2016, pp. 159-166.

Lai, J., Lui, S.S. and Tsang, E.W. (2016), "Intrafirm knowledge transfer and employee innovative behavior: the role of total and balanced knowledge flows", The Journal of Product Innovation Management, Vol. 33 No. 1, pp. 90-103.

Le, P.B. and Lei, H. (2018), "The mediating role of trust in stimulating the relationship between transformational leadership and knowledge sharing processes", Journal of Knowledge Management, Vol. 22 No. 3, pp. 521-537.

Lee, P., Gillespie, N., Mann, L. and Wearing, A. (2010), "Leadership and trust: their effect on knowledge sharing and team performance", Management Learning, Vol. 41 No. 4, pp. 473-491.

Leong, C.T. and Rasli, A. (2014), "The Relationship between innovative work behavior on work role performance: an empirical study", Procedia-Social and Behavioral Sciences, Vol. 129, pp. 592-600.

Lewicki, R.J., McAllister, D.J. and Bies, R.J. (1998), “Trust and distrust: new relationships and realities”, Academy of Management Review, Vol. 23 No. 3, pp. 438-458.

Lin, H.F. (2007), "Knowledge sharing and firm innovation capability: an empirical study", International Journal of Manpower, Vol. 28 Nos 3/4, pp. 315-332.

Liua, Y. and Phillips, J.S. (2011), "Examining the antecedents of knowledge sharing in facilitating team innovativeness from a multilevel perspective", International Journal of Information Management, Vol. 31 No. 1, pp. 44-52.

Majchrzak, A., Cooper, L.P. and Neece, O. (2004), "Knowledge reuse for innovation”, Management Science, Vol. 50 No. 2, pp. 174-188.

Matsuo, M. (2018), "Goal orientation, critical reflection, and unlearning: an individual-level study", Human Resource Development Quarterly, Vol. 29 No. 1, pp. 49-66.

Mayer, R.C., Davis, J.H. and Schoorman, F.D. (1995), “An integrative model of organizational trust”, Academy of Management Review, Vol. 20 No. 3, pp. 709-734.

McCauley, D.P. and Kuhnert, K.W. (1992), "A theoretical review and empirical investigation of employee trust in management", Public Administration Quarterly, Vol. 16 No. 2, pp. 265-284.

McEvily, B., Perrone, V. and Zaheer, A. (2003), "Trust as an organization principle”, Organization Science, Vol. 14 No. 1, pp. 91-103.

Michna, A., Kmieciak, R. and Brzostek, K. (2018), "Development of knowledge management processes in a small organization: a case study", in INTED2018 Proceedings. 12th International Technology, Education and Development Conference, Valencia, Spain, 5-7 March, 2018, pp. 3107-3114.

Michna, A. (2018), "The mediating role of firm innovativeness in the relationship between knowledge sharing and customer satisfaction in SMEs", Engineering Economics, Vol. 29 No. 1, pp. 93-103.

Mirzaee, S. and Ghaffari, A. (2018), "Investigating the impact of information systems on knowledge sharing", Journal of Knowledge Management, Vol. 22 No. 3, pp. 501-520.

Mishra, A.K. (1996), "Organizational responses to crisis: the centrality of trust", in Kramer, R. and Tyler, T. (Eds), Trust in Organizations, Sage, Thousand Oaks, CA, pp. 261-287..

Mueller, J. (2012), "Knowledge sharing between project teams and its cultural antecedents", Journal of Knowledge Management, Vol. 16 No. 3, pp. 435-447.

Mura, M., Lettieri, E., Radaelli, G. and Spiller, N. (2013), "Promoting professionals' innovative behaviour through knowledge sharing: the moderating role of social capital", Journal of Knowledge Management, Vol. 17 No. 4, pp. 527-544.

Nerstad, C.G.L., Searle, R.H., Cerne, M., Dysvik, A., Skerlavaj, M. and Scherer, R. (2018), "Perceived mastery climate, felt trust, and knowledge sharing”, Journal of Organizational Behavior, Vol. 39 No. 4, pp. 429-447. 
Ouakouak, M.L. and Ouedraogo, N. (2019), "Fostering knowledge sharing and knowledge utilization: the impact of organizational commitment and trust", Business Process Management Journal, Vol. 25 No. 4, pp. 757-779.

Paliszkiewicz, J. (2018), “Trust: a multifaceted notion”, in Kożuch, B., Magala, S.J. and Paliszkiewicz, J. (Eds), Managing Public Trust, Springer, Berlin, pp. 9-23.

Trust, knowledge sharing, and innovative work behavior

Paroutis, S. and Al Saleh, A. (2009), "Determinants of knowledge sharing using Web 2.0 technologies", Journal of Knowledge Management, Vol. 13 No. 4, pp. 52-63.

Peralta, C.F. and Saldanha, M.F. (2014), "Knowledge-centered culture and knowledge sharing: the moderator role of trust propensity", Journal of Knowledge Management, Vol. 18 No. 3, pp. 538-550.

Pittino, D., Martínez, A.B., Chirico, F. and Galván, R.S. (2018), "Psychological ownership knowledge sharing and entrepreneurial orientation in family firms: the moderating role of governance heterogeneity", Journal of Business Research, Vol. 84, pp. 312-326.

Plessis, M.D. (2007), "The role of knowledge management in innovation", Journal of Knowledge Management, Vol. 11 No. 4, pp. 20-29.

Podsakoff, P.M., MacKenzie, S.B., Lee, J. and Podsakoff, N.P. (2003), "Common method biases in behavioral research: a critical review of the literature and recommended remedies", The Journal of Applied Psychology, Vol. 88 No. 5, pp. 879-903.

Politis, J.D. (2003), "The connection between trust and knowledge management: what are its implications for team performance", Journal of Knowledge Management, Vol. 7 No. 5, pp. 55-66.

Radaelli, G., Lettieri, E., Mura, M. and Spiller, N. (2014), "Knowledge sharing and innovative work behaviour in healthcare: a micro-level investigation of direct and indirect effects", Creativity and Innovation Management, Vol. 23 No. 4, pp. 400-414.

Rao Jada, U., Mukhopadhyay, S. and Titiyal, R. (2019), "Empowering leadership and innovative work behavior: a moderated mediation examination", Journal of Knowledge Management, Vol. 23 No. 5, pp. 915-930.

Razmerita, L., Kirchner, K. and Nielsen, P. (2016), "What factors influence knowledge sharing in organizations? A social dilemma perspective of social media communication", Journal of Knowledge Management, Vol. 20 No. 6, pp. 1225-1246.

Renzl, B. (2008), "Trust in management and knowledge sharing: the mediating effects of fear and knowledge documentation”, Omega, Vol. 36 No. 2, pp. 206-220.

Rodan, S. and Galunic, C. (2004), "More than network structure: how knowledge heterogeneity influences managerial performance and innovativeness", Strategic Management Journal, Vol. 25 No. 6, pp. 541-562.

Rotter, J. (1967), "A new scale for measurement of interpersonal trust”, Journal of Personality, Vol. 35 No. 4, pp. 651-665.

Rousseau, D.M., Sitkin, S.B., Burt, R.S. and Camerer, C. (1998), "Not so different after all: a crossdiscipline view of trust", Academy of Management Review, Vol. 23 No. 3, pp. 393-404.

Rutten, W., Blaas-Franken, J. and Martin, H. (2016), "The impact of (low) trust on knowledge sharing", Journal of Knowledge Management, Vol. 20 No. 2, pp. 199-214.

Safari, A., Barzoki, A.S. and Heidari Aqagoli, P. (2020), "Exploring the antecedents and consequences of impersonal trust", ahead-of-print No. ahead-of-print, International Journal of Organizational Analysis. doi: 10.1108/IJOA-08-2019-1850.

Sanchez, G. (2013), PLS Path Modeling with R, Trowchez Editions, Berkeley.

Sankowska, A. (2013), "Relationships between organizational trust, knowledge transfer, knowledge creation, and firm's innovativeness", The Learning Organization, Vol. 20 No. 1, pp. 85-100.

Sarwar, A. and Mumtaz, M. (2017), "Empirical study on transformational and transactional leadership: exploring mediating role of trust in leader on organizational identification”, Paradigms, Vol. 11 No. 1, pp. 117-122. 
EJIM

24,5

1858

Scott, S.G. and Bruce, R.A. (1994), "Determinants of innovative behavior: a path model of individual innovation in the workplace", Academy of Management Journal, Vol. 37 No. 3, pp. 580-607.

Six, F. (2007), "Building interpersonal trust within organizations: a relational signaling perspective", Journal of Management and Governance, Vol. 11 No. 3, pp. 285-309.

Slavin, R.E. (1996), "Research on cooperative learning and achievement: what we know, what we need to know", Contemporary Educational Psychology, Vol. 21, pp. 43-69.

Spałek, S., Major, P. and Kowalewska, M. (2018), "Wpływ wybranych czynników na dzielenie się wiedza w projektach”, Management Forum, Vol. 6 No. 1, pp. 28-33.

Spanuth, T. and Wald, A. (2017), "How to unleash the innovative work behavior of project staff? The role of affective and performance-based factors", International Journal of Project Management, Vol. 35 No. 7, pp. 1302-1311.

Staples, D.S. and Webster, J. (2008), "Exploring the effects of trust, task interdependence and virtualness on knowledge sharing in teams", Information Systems Journal, Vol. 18 No. 6, pp. 617-640.

Straiter, K.L. (2005), "The effects of supervisors` trust of subordinates and their organisation on job satisfaction and organizational commitment", International Journal of Leadership Studies, Vol. 1 No. 1, pp. 86-101.

Stroebe, W. and Diehl, M. (1994), "Why groups are less effective than their members: on productivity loss in idea generating groups", European Review of Social Psychology, Vol. 5 No. 1, pp. 271-303.

Suppiah, V. and Singh Sandhu, M. (2011), "Organisational culture's influence on tacit knowledgesharing behavior", Journal of Knowledge Management, Vol. 15 No. 3, pp. 462-477.

Tenenhaus, M., Amato, S. and Esposito Vinzi, V. (2004), "A global goodness-of-fit index for PLS structural equation modelling", in Proceedings of the XLII SIS Scientific Meeting, CLEUP, Padova, pp. 739-742.

Tomlinson, E.C., Schnackenberg, A.K., Dawley, D. and Ash, S.R. (2020), "Revisiting the trustworthiness-trust relationship: exploring the differential predictors of cognition- and affect-based trust", Journal of Organizational Behavior, Vol. 41 No. 6, pp. 535-550.

Tschannen-Moran, M. and Hoy, W.K. (2000), "A multidisciplinary analysis of the nature, meaning, and measurement of trust”, Review of Educational Research, Vol. 70 No. 4, pp. 547-593.

Tzafrir, S.S. and Eitam-Meilik, M. (2005), "The impact of downsizing on trust and employee practices in high tech firms: a longitudinal analysis", Journal of High Technology Management Research, Vol. 16 No. 2, pp. 193-207.

van den Hooff, B. and de Ridder, J.A. (2004), "Knowledge sharing in context: the influence of organizational commitment, communication climate and CMC use on knowledge sharing", Journal of Knowledge Management, Vol. 8 No. 6, pp. 117-130.

Vaughn, K.S. (2011), The Constructs of Trust in Close Interpersonal Relationships, Ph.D. dissertation, University of Oklahoma, available at: https://shareok.org/handle/11244/319238 (accessed 27 May 2020).

Whisnant, B. and Khasawneh, O. (2014), "The influence of leadership and trust on the sharing of tacit knowledge: exploring a path model", Journal of Business Studies Quarterly, Vol. 6 No. 2, pp. 1-17.

Wu, W.L., Lin, C.H., Hsu, B.F. and Yeh, R.S. (2009), "Interpersonal trust and knowledge sharing: moderating effects of individual altruism and a social interaction environment", Social Behavior and Personality, Vol. 37 No. 1, pp. 83-93.

Yu, M.-C., Mai, Q., Tsai, S.-B. and Dai, Y. (2018), “An empirical study on the organizational trust, employee-organization relationship and innovative behavior from the integrated perspective of social exchange and organizational sustainability", Sustainability, Vol. 10 No. 3, p. 864.

Yuan, F. and Woodman, R.W. (2010), "Innovative behavior in the workplace: the role of performance and image outcome expectations", Academy of Management Journal, Vol. 53 No. 2, pp. 323-342. 
Yuan, Y.C., Zhao, X., Liao, Q. and Chi, C. (2013), "The usage of different information and communication technologies to support knowledge sharing in organizations", Journal of the American Society for Information Science and Technology, Vol. 64 No. 8, pp. 1659-1670.

Zand, D.E. (1972), "Trust and managerial problem solving”, Administrative Science Quarterly, Vol. 17 No. 2, pp. 229-239.

Zhang, W., Sun, S.L., Jiang, Y. and Zhang, W. (2019), "Openness to experience and team creativity: effects of knowledge sharing and transformational leadership", Creativity Research Journal, Vol. 31 No. 1, pp. 62-73.

Zhao, S., Jiang, Y., Peng, X. and Hong, J. (2020), "Knowledge sharing direction and innovation performance in organizations: do absorptive capacity and individual creativity matter?", aheadof-print No. ahead-of-print, European Journal of Innovation Management. doi: 10.1108/EJIM-092019-0244.

Zieba, M., Bolisani, E. and Scarso, E. (2016), "Emergent approach to knowledge management by small companies: multiple case-study research", Journal of Knowledge Management, Vol. 20 No. 2, pp. 292-307.

\section{Appendix}

\section{Scale Items}

Horizontal trust (HT)

HT1. I have trust in our team.

HT2. I can count on my co-workers when I really need them.

HT3. The atmosphere within the team is good.

Vertical trust (VT)

VT1. I trust my direct supervisor.

VT2. If I need my direct supervisor, he or she will be there for me.

VT3. My direct supervisor trusts me.

Knowledge donating (KD)

KD1. When I've learned something new, I tell my colleagues about it.

KD2. I share information I have with my colleagues.

KD3. I think it is important that my colleagues know what I am doing.

KD4. I regularly tell my colleagues what I am doing.

Knowledge collecting $(\mathrm{KC})$

$\mathrm{KC} 1$. When I need certain knowledge, I ask my colleagues about it.

KC2. I like to be informed of what my colleagues know.

KC3. I ask my colleagues about their abilities when I need to learn something.

$\mathrm{KC} 4$. When a colleague is good at something, I ask them to teach me how to do it.

Idea generation (IG)

IG1. I often searched for new working methods, techniques or instruments.

IG2. I often generated original solutions for problems.

IG3. I often found new approaches to execute tasks.

Idea realization (IR)

IR1. I often systematically introduced innovative ideas into work practices.

IR2. I often contributed to the implementation of new ideas.

IR3. I often put effort in the development of new ideas.

\section{Corresponding author}

Roman Kmieciak can be contacted at: roman.kmieciak@polsl.pl

For instructions on how to order reprints of this article, please visit our website:

www.emeraldgrouppublishing.com/licensing/reprints.htm

Or contact us for further details: permissions@emeraldinsight.com
Trust, knowledge sharing, and innovative work behavior

1859 